CHARLES J UNGLES NISZ LOURENÇO

\title{
Uma reflexão teórica para compreender as mudanças no Jornalismo com o uso de novas ferramentas tecnológicas
}




\section{Uma reflexão teórica para compreender as mudanças no Jornalismo com o uso de novas ferramentas tecnológicas}

Dissertação apresentada ao Programa de PósGraduação em Ciência da Comunicação, Linha de Pesquisa Estudo dos meios e da Produção Midiática, da Escola de Comunicação e Artes da Universidade de São Paulo, para obtenção do Título de Mestre, sob a orientação da Profa. Dra. Nancy Nuyen Ali Ramadan.

São Paulo 
Nome: LOURENÇO, Charles J ungles Nisz

Título: Uma reflexão teórica para compreender as mudanças no Jornalismo com o uso de novas ferramentas tecnológicas

Dissertação apresentada à Escola de Comunicação e Artes para obtenção do título de Mestre em Comunicação.

Aprovado em:

Banca Examinadora:

Prof. Dr.

Instituição:

Julgamento:

Assinatura:

Prof. Dr.

Instituição:

J ulgamento:

Assinatura:

Prof. Dr.

Instituição:

Julgamento:

Assinatura: 


\section{AGRADECI MENTOS}

À minha família - Antônio, Maria e Manuel - origem de tudo;

À Marcel Massa, J osé Carlos de Maria Jr, Ródson Oliveira, J oão Paulo Camargo, Renato Sanchez e Fellipe Abreu e Lima, pela amizade sincera.

À Rosana Soares e Cláudio Coelho pelas sugestões oferecidas durante a banca de qualificação.

À Maria Fernanda Degan Sanchez, por verter o resumo deste trabalho para o espanhol. À Renato Sanchez, uma vez mais, por verter o resumo para o inglês.

À Nancy Ramadan, pela orientação acadêmica e profissional durante esses dois anos e meio de Mestrado, por sua paciência, afinco, amizade e fidelidade.

À ECA e aos professores do Departamento de Jornalismo e Editoração, pela oportunidade de desenvolver este trabalho. 


\section{SUMÁRIO}

1. RESUMO página 06

2. INTRODUÇÃO página 09

2.1 Conceituando blogs e wikis página 11

2.2 Objetivos página 23

2.3 Procedimentos Metodológicos_ página 25

2.4 Hipóteses Iniciais Página 26

3. TEORI AS DA COMUNI CAÇÃO página 31

3.1 A Escola Funcionalista página 33

3.2 A Escola de Frankfurt página 39

3.3 Estudos Culturais e outras correntes teóricas página 44

3.4 A Epistemologia da Comunicação página 49

4. O J ORNALI SMO ENQUANTO CAMPO DE CONHECI MENTO página 61

4.1 Mudanças tecnológicas no Jornalismo página 71

5. UMA ALTERNATI VA TEÓRI CA PARA O J ORNALI SMO página 82

6. CONSI DERAÇÕES FI NAIS página 94

BIBLI OGRAFI A página 105 


\section{1 - RESUMO:}

Esta pesquisa teve como objetivo melhor dimensionar a chegada de novas tecnologias e as mudanças no fazer jornalístico com a chegada dessas ferramentas. Procuramos demonstrar que as abordagens teóricas tradicionais, como o funcionalismo norteamericano (décadas de 30 e 40) e as teorias da Escola de Frankfurt (análise marxista da comunicação) - não são capazes de explicar as mudanças sofridas pelo J ornalismo na última década. Há um problema de ordem epistemológica e metodológica: qual deve ser a abordagem teórica para compreender a chegada de ferramentas tecnológicas como os wikis e os blogs? Essas ferramentas estão alterando as rotinas de apuração, produção, edição e veiculação de notícias. A idéia é a de refletir sobre o surgimento de outros referenciais teóricos mais eficientes para dimensionar o quadro atual; a saber, a teoria de sistemas emergentes e a teoria da complexidade.

PALAVRAS-CHAVE: J ornalismo, teoria, blogs, wiki, complexidade. 


\section{ABSTRACT:}

This research aims to discuss the arrival of new technologies and how these new tools are changing the way journalism is done. We try to demonstrate that the traditional theorical approaches are not capable of explaining Journalism after its changes in the last decade. There is an epistemologic and metodologic question: what is the appropriate theorical approach to understand the arrival of technologic tools such wiki and blogs. They are changing the way news are investigated, produced, edited and vehicled. The main idea is think about the rise of new theoric references in the endeavor of understanding all these changes: the complexity theory and the theory of emerging systems.

KEYWORDS: J ournalism, theory, blogs, wiki, complexity; 


\section{RESUMEN}

Esta investigación tiene el objetivo de dimensionar la llegada de nuevas tecnologias y los cambios en el que hacer periodístico a partir de esta misma llegada. Procuramos demonstrar que los abordajes teóricos tradicionales - el funcionalismo norte-americano (décadas de 30 y 40) y las teorías de la Escuela de Frankfurt (análisis marxista de la comunicación) - no son capaces de explicar los cambios sufridos por el Periodismo em la última década. Hay un problema de orden epistemológico y metodológico: cual debe ser el abordaje teórico para compreender la llegada de herramientas tecnológicas como los wikis y los blogs? La idea es pensar el surgimiento de otros referenciales teóricos más efectivos para dimensionar el cuadro actual, es decir, la teoría de sistemas emergentes y la teoría de la complejidad.

PALABRAS CLAVES: Periodismo, teoria, blogs, wiki, complejidad; 


\section{2 - I NTRODUÇÃO}

Criada em 1989, a rede World Wide Web foi idealizada por Tim Barners-Lee, pesquisador no Centro Europeu de Pesquisa Nuclear (CERN, na sigla francesa), para compartilhar a documentação eletrônica usada na construção do acelerador de partículas Grande Colidor de Hádrons (LHC, na sigla inglesa). O equipamento é o maior acelerador de partículas do mundo e é utilizado para estudar a origem da massa das partículas elementares da matéria.

A partir da junção dos protocolos URL (responsável pelo endereço dos sites), HTTP (responsável pela comunicação entre o navegador e o servidor web) e o HTML (linguagem de marcação para codificar dados), o protocolo Web passou a ser utilizado para aplicativos como o e-mail e páginas informativas.

Com o avanço destas novas tecnologias, o jornalismo na Internet e mesmo o jornalismo impresso vêm sofrendo uma série de mudanças no seu fazer. Ferramentas como os wikis permitem maior colaboração na produção e edição das matérias. Os blogs, por sua vez, proporcionam maior diversificação das fontes noticiosas, ampliando o espectro informativo do leitor.

Interatividade, aqui entendida como o potencial de uma mídia em permitir que o usuário tenha influência sobre o conteúdo, e velocidade são as principais características do Jornalismo transformado pelas novas tecnologias da informação e comunicação. 
Especialistas em mídia mostram também a importância dos comentários em blogs e nas notícias veiculadas nos portais informativos.

Para analisar todas essas transformações na prática jornalística, partimos do campo da Comunicação, fazendo uma retomada das teorias - a escola funcionalista americana, a Escola de Frankfurt, os chamados Estudos Culturais e as Ciências da Linguagem, enfocando a necessidade de uma metodologia de pesquisa e de prática para esse campo do conhecimento.

A segunda parte da pesquisa se destina a focar a análise na Teoria do Jornalismo. 0 intuito é mostrar como o novo cenário tecnológico faz necessária uma outra abordagem teórico-conceitual para o J ornalismo, especialmente aquele praticado em mídias digitais. A saber, a teoria de sistemas emergentes e a teoria da complexidade. 


\subsection{CONCEITUANDO BLOGS E WI KIS}

0 termo blog vem de weblog e foi cunhado em 17 de dezembro de 1997 por Jorn Barger, para referir-se a um conjunto de sites que "colecionavam" e divulgavam links interessantes na web, segundo (Blood, 2000), como o Robot Wisdom, site do próprio Barger. Daí o termo "web" + "log" (arquivo web), usado por Barger para descrever a atividade de "mapear a rede". ${ }^{1}$

Naquela época, os weblogs eram poucos e quase nada diferenciados de um site comum na Internet. Talvez por conta desta semelhança, autores como David Winer considerem como o primeiro weblog o primeiro site da web, mantido por Tim Berners-Lee, no CERN. O site tinha como função listar todos os novos sites que eram colocados no ar e disponibilizados na rede mundial de computadores. ${ }^{2}$

A blogosfera, termo que representa o mundo dos blogs, ou os blogs como uma comunidade ou rede social, cresceu em ritmo espantoso. Em 1999 o número de blogs era estimado em menos de 50; no final do ano 2000, a estimativa era de poucos milhares. Menos de três anos depois, os números saltaram para algo entre 2,5 a 4 milhões.

\footnotetext{
${ }^{1}$ Cf. http://pontomidia.com.br/raquel/AmaralMontardoRecuero.pdf, pág. 1

${ }^{2}$ Idem, Idem.
} 
Atualmente existem cerca de 112 milhões de blogs e cerca de 120 mil são criados diariamente, de acordo com o estudo State of Blogosphere. ${ }^{3}$ Segundo reportagem da BBC, publicada em 2 de agosto de 2005, "um blog é criado a cada segundo no mundo". ${ }^{4}$

O crescimento do número de blogs existentes é explicado pelo surgimento de ferramentas de publicação. Esses sistemas de publicação e edição de páginas web deixaram mais simples a criação e a manutenção das páginas por terem uma interface visual e dispensarem o conhecimento da linguagem HTML. A agregação de comentários aos conteúdos postados também serviu para aumentar a popularidade desse novo meio de comunicação.

Inicialmente, essas ferramentas foram utilizadas como diários pessoais, por vezes, ainda o são. Guardando muita semelhança com os diários em papel, esses sites serviram como repositório para desabafo de experiências, pensamentos e das atividades cotidianas do editor do blog. Segundo pesquisa da Verbeat.org sobre a blogosfera brasileira, publicada em 2006, 48,3\%, dos blogueiros tem como principal motivação para manter o seu site o "registro de pensamentos e idéias do autor do site". ${ }^{5}$

Estruturalmente falando, na explicação de Blood (2002), os blogs têm três características de publicação: links apontando para publicações semelhantes,

\footnotetext{
${ }^{3}$ Disponível em: http://technorati.com/weblog/blogosphere/

${ }^{4}$ Disponível em: http://news.bbc.co.uk/2/hi/technology/4737671.stm

${ }^{5}$ Disponível em: http://www.verbeat.org/pesquisablogosferabrasil/
} 
atualização constante e textos publicados em ordem cronológica inversa. ${ }^{6}$ As duas últimas características bem poderiam ser aplicadas aos jornais impressos e mais ainda aos sites noticiosos.

Schmidt (2007, online), explica que blogs são:

Websites freqüentemente atualizados onde o conteúdo (texto, fotos, arquivos de som, etc) são postados em uma base regular e posicionados em ordem cronológica reversa. Os leitores quase sempre possuem a opção de comentar em qualquer postagem individual, identificada com uma URL única. ${ }^{7}$

Outra vertente prefere analisar os blogs de acordo com suas características funcionais, a partir de uma ótica comunicacional. Marlow (2004, online), considera os blogs uma mídia diferente dos veículos tradicionais por seu caráter dialógico, expresso nos comentários e outras ferramentas de conversação utilizadas nesse tipo de site. Nessa visão, os blogs são encarados como uma forma de midiatizar informações. Segundo pesquisa da Verbeat.org, 61,4 dos blogueiros percebe a plataforma com uma mídia alternativa. ${ }^{8}$

Uma terceira visão percebe os blogs também como um mecanismo fomentador de conversação, como espaços de sociabilidade e como agregador de comunidades. Essa

\footnotetext{
${ }^{6} \mathrm{Cf}$. http://pontomidia.com.br/raquel/AmaralMontardoRecuero.pdf, pág. 2.

${ }^{7}$ Disponível em: http://jcmc.indiana.edu/vol12/issue4/schmidt.html

${ }^{8}$ Disponível em http://www.verbeat.org/pesquisablogosferabrasil/
} 
vertente entende os blogs "enquanto artefatos culturais, como repositório de idéias e trocas de links de determinados grupos no ciberespaço". ${ }^{9}$ Pensar os blogs nesse sentido mais amplo de comunicação também implica entender a utilização dessa ferramenta para práticas jornalísticas.

Jay Rosen, professor de Jornalismo na New York University não acredita no uso dos blogs para fins jornalísticos. No entanto, nosso trabalho percebe os blogs enquanto uma ferramenta, uma plataforma que pode ser utilizada também para disseminar conteúdos e informações na Internet.

Portanto, neste caso, a pergunta a se fazer é: como é possível fazer jornalismo utilizando os blogs? Blogs podem ser usados para divulgar links, fotos, relatos pessoais, diários e muito mais. Importa é examinar como jornalistas podem utilizar essa plataforma e mudar a relação entre o J ornalismo e as novas tecnologias.

Desde o seu surgimento, o jornalismo cumpre uma função social, a de fazer circular informação na sociedade e, com isso, municiar o senso crítico dos cidadãos. Esse princípio fundador, em boa medida, ajuda a manter os regimes democráticos. Lembremos a simultaneidade entre o surgimento do Jornalismo e dos ideais liberais no fim do século XVIII, na revolução Francesa.

\footnotetext{
${ }^{9}$ Cf. http://pontomidia.com.br/raquel/AmaralMontardoRecuero.pdf, pág. 4.
} 
O segundo aspecto do Jornalismo a ser levado em conta é o seu caráter institucional, cuja feição mais visível é o seu discurso. Isso explica a forte vinculação entre os estudos de análise do discurso e a mídia. A sociedade identifica e legitima o Jornalismo enquanto portador de um discurso e the outorga o poder de "fiscalizar" as outras instâncias estatais - Executivo, Legislativo e Judiciário.

Mas há uma grande diferença entre os blogs e as mídias tradicionais. Há um forte caráter opinativo nos diários virtuais. Os blogs não têm somente a pretensão informativa dos veículos midiáticos usuais - isso implode as noções de objetividade e imparcialidade, necessários à legitimação do J ornalismo, como o conhecíamos até então.

Por conta do seu caráter opinativo, os blogs têm um discurso mais característico do que o apresentado pelos jornais. Em última instância, ele é a voz de uma pessoa, tem identidade, personalidade e opinião. Assim sendo, ela pode - e deve - ser debatida. A caixa de comentários dos blogs trouxe uma dimensão perdida pelo Jornalismo de massa.

Essa dimensão é a esfera pública, definida pelo filósofo alemão Jurgen Habermas como "a esfera das pessoas privadas reunidas em um público [...] a fim de discutir [com as autoridades] as leis gerais da troca na esfera fundamentalmente privada, mas 
publicamente relevante, as leis do intercâmbio de mercadorias e do trabalho social". ${ }^{10}$ Nesse sentido, os blogs podem ser mais democráticos do que as mídias tradicionais.

Ao assumir as funções e o discurso característico dos veículos de mídia, os blogs podem ser uma alternativa aos meios de comunicação já instituídos. Mas, nesse caso, acontecem mudanças na rotina de produção jornalística. Alteram-se os critérios de seleção, enfoque, edição e credibilidade noticiosa.

Mas há problemas com a nova plataforma utilizada para fazer Jornalismo. A confiança nesses veículos é abalada quando uma informação é publicada sem a devida checagem. Esse problema já ocorria em mídias tradicionais e agora pode ser amplificado pelas novas ferramentas para fazer Jornalismo. Isso pode atrasar o uso dos blogs como plataforma para disseminar notícias e informações.

Outra ferramenta tecnológica utilizada como plataforma jornalística são os wikis. Wiki é um termo proveniente do idioma havaiano, que significa "rápido". ${ }^{11}$ Um Wiki é um conjunto editável de páginas na Internet. Sua principal diferença em relação ao Jornalismo tradicional, e também em relação aos blogs, é seu caráter colaborativo.

Como as páginas são facilmente criadas e alteradas, isso proporciona rapidez na publicação e principalmente, na edição do conteúdo. Por isso, em menos de dez anos o

10 Cf. HABERMAS, Jürgen. Mudança estrutural da esfera pública: investigações quanto a uma categoria da sociedade burguesa. Rio de Janeiro, Tempo Brasileiro, 1984.

${ }^{11}$ Cf. http://pt.wikipedia.org/wiki/Wiki 
wiki se tornou uma ferramenta extraordinária para a criação cooperativa de hipertextos - inclusive jornalísticos.

Wikis simples permitem apenas a formatação básica, enquanto os mais complexos suportam tabelas, imagens, fórmulas, ou até elementos interativos, como votações e jogos. São mídias hipertextuais, com estrutura de navegação não-linear e cada página geralmente contém um grande número de ligações para outras páginas.

A Wikipedia ${ }^{12}$ - a enciclopédia livre - foi ao ar em 15 de Janeiro de 2001, e hoje é, de longe, o wiki com mais páginas e conteúdo informativo. Em junho de 2004, a Wikipedia apresentava quase 300.000 verbetes (a tradicional Enciclopédia Britannica tem 100.000). A qualidade da informação encontrada na Wikipedia é desigual. Quanto mais popular um assunto, melhor a qualidade dos verbetes associados àquele tema.

Alguns especialistas em Jornalismo acreditam que a evolução dos blogs estaria no wiki. É a possibilidade de uma reportagem ser escrita por mais de duas mãos. Da mesma maneira que os blogs, caso isso aconteça, o wiki provocará forte mudança nas rotinas de produção do J ornalismo.

Uma das principais mudanças está no conceito de autoria. Um texto jornalístico, por definição, tem autoria bem definida e delimitada. Mas como definir a propriedade de um texto onde um grande número de pessoas participa da apuração, produção, edição e

\footnotetext{
${ }^{12}$ Cf. http://en.wikipedia.org
} 
correção da reportagem? Como a autoria é sempre compartilhada, não há um dono do produto final.

Paul Bradshaw, professor de Jornalismo online e novas mídias da Universidade de Birmingham ${ }^{13}$, identificou cinco utilizações possíveis do wiki para a produção de textos noticiosos ou jornalísticos ${ }^{14}$ :

a)Leitores podem editar um texto produzido por repórteres profissionais;

b)J ornalistas e leitores editam material de outras fontes;

c) Leitores agregam informações a um texto sem alterar o conteúdo original;

d)Produção e edição sem agenda estabelecida - isso mina o conceito de deadline;

e)Produção coletiva de reportagens por repórteres de um mesmo veículo;

Mas o sistema tem riscos que não podem ser minimizados e muito menos ignorados. 0 principal deles é o vandalismo informativo. Outros perigos são a falta de exatidão e dúvidas sobre a credibilidade de notícias.

O ponto negativo é o mesmo dos blogs: a credibilidade da informação. Poucas vezes há revisão antes da veiculação do conteúdo. Além disso, os textos são abertos e há o risco de que a informação seja alterada propositadamente. Espera-se, portanto, confiança na auto-regulação do sistema editorial.

\footnotetext{
${ }^{13}$ Cf. http://www.cardiff.ac.uk/jomec/en/research/28/369.html

${ }^{14}$ Cf. http://herdeirodocaos.com/?p=103
} 
Até agora não foi descoberta nenhuma forma de impedir a alteração proposital dos conteúdos publicados por meio de ferramentas wiki com o objetivo de prejudicar os autores desses artigos. Quanto maior a utilização e visitação do site, mais fácil a prevenção desse tipo de vandalismo virtual.

Os 1,5 milhões de visitantes diários da Wikipedia permitem a detecção rápida dessas ações maldosas e também os erros cometidos de modo não intencional, garantindo em termos - a qualidade da informação no site.

Conforme a opinião do professor Bradshaw, exposta na lista acima há outro problema com a utilização de ferramentas wiki. Jornalistas estão acostumados a trabalhar com rotinas tradicionais de apuração e edição. Mas o jornalismo online tem um processo de fechamento contínuo - os textos são freqüentemente alterados. O sistema wiki precisará ser mais testado. Mas, tudo indica, será uma ferramenta permanente nas redações jornalísticas.

Um dos efeitos de todas essas mudanças é a queda do nível das vendas de jornais. Entre 2000 e 2004, a circulação de jornais no Brasil por mil habitantes caiu cerca de $21 \% \cdot{ }^{15}$ Em termos de vendagem, o primeiro trimestre de 2009 foi o pior dos últimos 10 anos para os três maiores jornais brasileiros.

\footnotetext{
${ }^{15}$ DENICOLI, S. Vendas de jornais impressos em queda acentuada, Ponto de análise, São Paulo, 13 de março de
} 2006. Disponível em <http://pontodeanalises.blogspot.com/2006/03/venda-de-jornais-impressos-em-queda.html> 
“Líder do ranking, a Folha de S. Paulo começou o ano 2000 com média diária de 429.476, foi caindo ano após ano até fechar o primeiro trimestre de 2009 com 298.352. O mesmo ocorreu com seu maior concorrente, O Estado de S. Paulo, que registrou queda de 391.023 para 217.414. No Rio de Janeiro o cenário não é muito diferente, já que $\boldsymbol{O}$ Globo começou o ano 2000 com média diária de 334.098 e fechou o primeiro trimestre de 2009 com 260.869, número superior apenas a outros dois anos desta década: 258.485, em 2003, e 250.480, em 2004" ${ }^{16}$.

No exterior, a tendência permanece: entre setembro de 2008 e março de 2009, as vendas diárias de jornais nos Estados Unidos caíram 7\%, em relação ao mesmo período de 2007/2008. Algumas quedas foram acentuadas: o Boston Globe perdeu 13.6\%, 0 New York Daily News caiu 14\% e o The New York Post vendeu 20\% a menos.

Outras grandes quedas de vendagem aconteceram com o The Miami Herald(15.8\%); The San Francisco Chronicle (15.7\%); The Philadelphia Inquirer (13.7\%); The Atlanta Joumal-Constitution (20\%). O USA Today, líder de vendas diárias nos EUA, perdeu 7,4\%, obtendo uma tiragem média de 2.113 .725 exemplares $^{17}$.

Para enfrentar as mudanças no modo de fazer Jornalismo é necessário entender como as novas plataformas tecnológicas estão sendo usadas e também especular sobre outras maneiras de utilizá-las, de modo a explorar todo o potencial técnico e estético dessas

\footnotetext{
${ }^{16}$ LEMOS, A. Grandes jornais têm pior circulação da década. Meio e mensagem, São Paulo, 28 de abril de 2009. Disponível em http://www.meioemensagem.com.br/novomm/br/

${ }^{17}$ GREENSLADE, R. US Newspaper sales fall further. The Guardian, Londres, 28 de abril de 2009. Disponível em <http://www.guardian.co.uk/media/greenslade/2009/apr/28/us-press-publishing-abcs>
} 
ferramentas. Também será preciso entender o público que navega na Internet - mais informado e com uma postura mais ativa diante da notícia - de modo a conceber um noticiário pertinente à essa audiência.

Portanto, muda o perfil do jornalista - havendo uma maior simbiose entre repórteres e editores - e se alteram os critérios de edição, fechamento e velocidade. 0 processo de edição, desde a pauta à publicação da notícia, passa a ser permanente. A complementação das matérias é feita sempre que necessário e a atualização do noticiário é constante.

A pergunta fundamental a fazer é se jornalistas e acadêmicos estão pensando em teorias para entender todas essas mudanças. Se há metodologia para criar novas maneiras de estudar a Comunicação. Quais devem ser os parâmetros técnicos, éticos e estéticos do J ornalismo do século XXI?

Em nosso quadro teórico de referência, foram revistos autores pioneiros que se preocuparam com o conhecimento conceitual sistematizado na área da Comunicação Social como Martino (2007, org.), Santos (1992) e também da área de Jornalismo como Pena (2005), Traquina (2004), Lage (2001), Kunczik (1997) Chaparro (1993), Meditsch (1992), entre outros. 
Para estudar esta temática tendo em vista o processo de globalização e novas tecnologias da informação também foi revista bibliografia pertinente, especialmente os trabalhos de autores como Martin-Barbero (1997), Hall (2000), Johnson (2003) e Castells (2000). 


\section{2 - OBJ ETI VOS}

A justificativa para este trabalho se dá pela necessidade de aprofundar os estudos sobre as novas abordagens teóricas para analisar o Jornalismo na atualidade. Estudos acadêmicos sobre teoria da complexidade e sistemas caóticos aplicados ao Jornalismo ou mesmo à Comunicação são ainda escassos. A comprovação pode ser feita numa consulta às bases de dados das principais bibliotecas dos cursos de Comunicação do Estado de São Paulo.

Na biblioteca da ECA/USP não há nenhuma obra sobre inteligência coletiva ou sistemas auto-organizáveis. Na PUC/SP há quatro obras sobre o primeiro tema e duas sobre 0 segundo: Teoria dos sistemas, L. von Bertalanffy; tradução de Maria da Graça L. Becskehazy; Emergência: a dinâmica de rede em formigas, cérebros, cidades e softwares, Steven Johnson; tradução de Maria Carmelita Pádua Dias, Rio de Janeiro, 2003.

Por fim, apenas quatro títulos relacionados na Unicamp: Inteligência Coletiva, Levy, Loyola, 1998; Chaos: an introduction to dynamical systems, de Kathleen T. Alligood, Spring, 1996; Incompletude e auto-organização: sobre a determinação de verdades logicas e matemáticas, de Ricardo Pereira Tassinari, Campinas 2003; Teoria dos sistemas, L. von Bertalanffy; tradução de Maria da Graça L. Becskehazy; Teoria dos sistemas e epistemologia, de Pierre Delattre. 
Sabemos que, no que diz respeito à bibliografia mais atual, alguns autores como Henn (1997) e Johnson (2003) tratam do assunto, porém abordam essas novas teorias mais especificamente para a Comunicação como um todo e para tratar de sistemas autoorganizáveis. A intenção é verificar a aplicabilidade dessas metodologias para o Jornalismo.

Essas teorias, aliadas aos estudos de pesquisadores como Van Dijk (1997) - que abordam a questão do Jornalismo enquanto instância produtora de conhecimento poderiam explicar de modo mais satisfatório as relações que o fazer jornalístico engendra.

A hipótese central desse trabalho é que as abordagens atuais já não se sustentam para analisar o Jornalismo da forma como ele se configura hoje. A intenção é fazer uma revisão dessas abordagens, comparando-as com outras teorias que abrangem o Jornalismo sob a perspectiva de um sistema que se relaciona com a sociedade e perceber a estruturação interna do J ornalismo enquanto forma de conhecimento, prática profissional e técnica. 


\section{3 - PROCEDI MENTOS METODOLÓGI COS}

A metodologia usada foi a Pesquisa Bibliográfica e Documental e a observação de sites e blogs jornalísticos. Dados os objetivos acima, procuraremos adotar na análise os seguintes procedimentos:

a) Confrontar as abordagens teóricas acadêmicas sobre o Jornalismo predominantes nos dias atuais. Relacionar essas aproximações com a metodologia de avaliação da produção cientifica na área adotada pelas agências de fomento no Brasil. Abordar o Jornalismo enquanto instância de produção de conhecimento e comparar o estatuto desse conhecimento com a Ciência, que é a forma de conhecimento reconhecida a priori.

b) Analisar os fundamentos teóricos de cada uma das abordagens teóricas sobre 0 Jornalismo, explicando o porquê da sua insuficiência para explicar a dinâmica do Jornalismo atual. Apresentar a emergência das novas teorias e mostrar de que forma elas podem ajudar a delinear um panorama conceitual para o campo jornalístico.

c) Apresentar as novas abordagens para o estudo do Jornalismo, a saber, as teorias da complexidade e de outros campos do conhecimento, como a termodinâmica, e outras contribuições trazidas de campos do conhecimento que não sejam as humanidades. 


\section{4 - HI PÓTESES I NI CI AIS}

1) A hipótese central desse trabalho é que as abordagens acadêmicas tradicionais já não se prestam, ou não se sustentam, para analisar o Jornalismo da forma como ele se configura hoje.

2) Hipóteses secundárias:

a) O Jornalismo é um sistema que interage com a sociedade.

b) É possível construir uma teoria para analisar as mudanças do J ornalismo

Pretende-se detectar as principais deficiências das teorias já consagradas sobre o J ornalismo, relacionando-as com as mudanças causadas pelo uso de novas ferramentas tecnológicas. Este trabalho é um estudo descritivo que tem como fim levantar dados sobre o tema e organizá-los para oferecer novas pistas, uma vez que o surgimento de blogs e wikis conta apenas uma década. Ambas as ferramentas são utilizadas de modo jornalístico há menos de 10 anos.

A idéia inicial deste projeto era discutir o status epistemológico do Jornalismo, comparando esse campo do conhecimento com a Ciência, instância produtora de conhecimento por excelência. Porém, tendo em vista as recentes - muito novas mudanças referidas, do que vemos diariamente na web, e as sugestões da Banca de Qualificação, o foco principal ganhou novos contornos, passando a discutir as relações entre a produção jornalística e as novas tecnologias da informação. 
“Para comprovar, ou não, as referidas hipóteses, partimos do pressuposto de que outros campos do conhecimento, principalmente a Medicina e o Direito, ainda que não se configurem como disciplinas científicas, alcançaram um status epistemológico mais elevado do que o conseguido pelo Jornalismo - hoje uma linha de pesquisa no campo da Comunicação. A despeito da enorme diferença de tempo de desenvolvimento entre 0 Jornalismo e o Direito e a Medicina - ambos os campos têm mais de dois milênios de prática e concepção teórica - intriga descobrir quais os procedimentos executados por essas duas áreas para conseguir este reconhecimento acadêmico. Queremos investigar a possibilidade de construção de algo análogo para o Jornalismo". ${ }^{18}$

Nesse sentido, vale lembrar o que diz Lee Bollinger, reitor da Faculdade de Jornalismo de Colúmbia, uma das mais prestigiosas faculdades no ensino da disciplina em todo o mundo:

"Ao contrário do direito, o jornalismo não seria um campo do conhecimento, e sim um processo de investigação crítica? Não estou assim tão certo disso. Acho que é uma questão aberta e muito importante. Não estou convencido de que não haja um campo de conhecimento a ser trabalhado nas escolas de Jornalismo, à semelhança do ensino de Direito, Economia ou mesmo Arte, no sentido de que os estudantes usem conhecimentos no processo de aplicação das técnicas da profissão. Certamente há grandes obras do Jornalismo que podem ser proficuamente revistas, desembrulhadas,

\footnotetext{
${ }^{18}$ Trecho do projeto de pesquisa apresentado na seleção para o mestrado
} 
examinadas com olho crítico. E nesse processo desenvolvem-se hábitos mentais que podem ser úteis quando o jornalista for apurar novas matérias". ${ }^{19}$

A proposta inicial foi redirecionada (poderá ser retomada num futuro trabalho) já que, apesar de enriquecer a pesquisa, abriria demais o escopo deste trabalho. Assim, optei por trabalhar apenas junto às mudanças sofridas pelo Jornalismo em termos metodológicos da sua prática. Mas compreendo que a chegada de novas plataformas tecnológicas também traz embutidas mudanças epistemológicas para o J ornalismo que, ainda que em parte, procuramos contemplar nas discussões aqui apresentadas.

De qualquer forma, registro a necessidade de futuros trabalhos acadêmicos para discutir o Jornalismo em suas bases. Não é uma discussão simples, pois traz questionamentos metodológicos e epistemológicos, ou seja, será preciso discutir a possibilidade do J ornalismo ganhar o status de disciplina ou ciência ${ }^{20}$.

Começamos a redigir o projeto de pesquisa para esta dissertação em abril de 2006. Conforme exposto acima, a idéia era a de questionar o status epistemológico do Jornalismo em comparação com a Ciência. Iniciamos a leitura de livros sobre essa temática, como "O fim da ciência", de John Horgan ${ }^{21}$ e livros sobre teoria do

\footnotetext{
19 “Cf. ENTREVISTA / Lee Bollinger - O jornalismo na visão do reitor”, Observatório da Imprensa, http://www.observatoriodaimprensa.com.br/artigos/da201120022.htm.

${ }^{20}$ RAMADAN, N. Tese de Livre-docência, “O Jornalismo online visto pelos pesquisadores em São Paulo: a fragilidade das pesquisas que fazem escola (equivocada) nos bancos da graduação”, ECA-USP, agosto de 2008.

${ }^{21}$ HORGAN, J. O Fim da Ciência - Uma discussão sobre os limites do conhecimento científico, Cia das Letras, São Paulo, 1998.
} 
J ornalismo como "Teorias do Jornalismo", de Felipe Pena ${ }^{22}$ e o livro do mesmo nome, do professor português Nélson Traquina ${ }^{23}$.

Ao ingressar no mestrado, cursei as disciplinas Nova Teoria da Comunicação Complexidade, Auto-organização e Autopoiese e Ciências da linguagem: mídias e estigmas sociais. Por conta dessas disciplinas, houve a necessidade de um estudo mais aprofundado das Teorias da Comunicação.

Para suprir essa necessidade e entender as relações entre a linguagem, as teorias do Jornalismo e as Teorias da Comunicação, busquei referências ao ler os textos de Heinz von Foerster, Gregory Bateson, Humberto Maturana e Michel Serres. Esses quatro autores são pesquisadores destacados na corrente teórica conhecida como Nova Teoria da Comunicação.

Também cursei as disciplinas Metodologia de webdesign baseada em usabilidade para comunicação efetiva e eficiente da informação e Alternativas do Conhecimento Científico em Cultura e Comunicação Social. A primeira delas trouxe a perspectiva da junção entre o conteúdo e a forma na apresentação e veiculação das notícias. Essa é uma constatação fundamental quando estamos falando de J ornalismo online.

\footnotetext{
${ }^{22}$ PENA, F. Teoria do Jornalismo, Editora Contexto, São Paulo, 2005.

${ }^{23}$ TRAQUINA N. Teorias do Jornalismo - a tribo jornalística, uma comunidade transnacional, volume II, Insular, Florianópolis, 2005.
} 
Já a disciplina de Alternativas do Conhecimento Científico em Cultura e Comunicação mostrou a necessidade de uma maior fundamentação metodológica na construção e estudo do objeto da Comunicação. A partir daí, procuramos estudar a história das Teorias da Comunicação e as suas dificuldades metodológicas.

Alguns dos livros a nos auxiliar nessa tarefa foram "Introdução à Teoria da Comunicação", de Roberto Elísio dos Santos ${ }^{24}$ e "Teorias da Comunicação: muitas ou poucas?', organizado por Luiz Carlos Martino ${ }^{25}$, pesquisador da área. Estes estudos permitiram uma discussão mais adequada e aprofundada em torno do tema, como veremos a seguir.

${ }^{24}$ SANTOS, R. Introdução à teoria da Comunicação, São Bernardo do Campo, Editora Bartira, 1992.

${ }^{25}$ MARTINO, Luiz C. Martino (org.), Charles R. Berger e Robert T. Craig, Ateliê Editorial , 2007. 


\section{3 - TEORIAS DA COMUNI CAÇÃO}

No último século, diversos autores têm tentado sistematizar e classificar as teorias sobre a comunicação humana. Iremos relembrar e retomar as principais teorias da Comunicação para mostrar a trajetória deste campo e tentar apontar por quê essas teorias não dão conta de compreender o jornalismo praticado nos meios digitais, usando a Internet como plataforma.

A idéia deste capítulo é mostrar qual é a fundamentação teórica do chamado "campo" da Comunicação e mostrar como essas teorias derivam para as teorias do J ornalismo ou para as teorias da notícia. Os estudos sobre Comunicação desenvolveram-se, principalmente, no início do século XX.

Apesar da importância da Comunicação para a espécie humana, foram necessários mais de 200 anos de imprensa escrita, da popularidade do rádio e da literatura popular e do advento do cinema para surgirem os primeiros estudos acadêmicos sobre o tema.

Resumindo, foi somente após a criação dos meios de comunicação de massa que a Academia resolveu se debruçar sobre as origens, causas e efeitos da Comunicação na vida moderna. Graças a essas pesquisas, iniciadas majoritariamente nos Estados Unidos, começou a acontecer a conceitualização dos fenômenos de Comunicação. 
Uma das definições sobre esse campo parte da etimologia. Segundo a origem da palavra, "comunicação dá o sentido de comunidade, de tornar algo comum a todos". ${ }^{26}$ Outra definição, biológica, entende a comunicação "como uma atividade sensorial e nervosa, na qual se transmitem informações". 27

Já para Bordenave, a Comunicação "é parte de um processo mais amplo, o de informação". ${ }^{28}$ E este último, é um aspecto do processo de organização (social, política, econômica, administrativa, etc). Então, percebemos que a trajetória iniciada com Aristóteles e seu modelo comunicacional composto por três elementos (locutor, discurso e ouvinte), exposto na Retórica, está longe de terminar ou ter chegado a um acordo sobre as bases da Comunicação.

Da virada do século XX até os dias atuais, dezenas de teorias e modelos buscam entender a Comunicação e também o Jornalismo. Neste trabalho apresentaremos três grupos dessas teorias - Escola Americana ou Funcionalista, Escola de Frankfurt, as Ciências da Linguagem e os chamados Estudos Culturais - e mostraremos as falhas dessas concepções no entendimento do Jornalismo. Por fim, apresentaremos as chamadas teorias de sistemas e da complexidade, na tentativa de propor um modelo para entender o surgimento de novas mídias.

\footnotetext{
${ }^{26}$ SANTOS, R. Introdução à teoria da Comunicação, São Bernardo do Campo, Editora Bartira, 1992, pág. 9.

${ }^{27}$ Idem, pág. 10.

28 BORDENAVE, J. O que é Comunicação?, São Paulo, Brasiliense, 1982.
} 


\section{1 - A ESCOLA FUNCI ONALISTA}

A teoria funcionalista leva esse nome por creditar às funções exercidas pelos membros de uma sociedade as razões de sua sobrevivência. Essas teorias são herdeiras do positivismo instituído por Auguste Comte no século XIX.

Buscar a compreensão dos fenômenos sociais com o mesmo rigor utilizado nas ciências exatas era o objetivo desses pesquisadores. A pesquisa empírica era o método usado para investigar os efeitos das mensagens na comunicação de massa.

A utilização da propaganda nos Estados Unidos foi o impulso inicial desses estudos, iniciados na década de 30 do século passado. Robert Merton, Paul Lazarsfeld e Harold Lasswell são os principais autores relacionados à essa corrente teórica.

Os teóricos funcionalistas procuraram aferir o alcance dos meios de comunicação junto ao público. A influência desses meios no comportamento das massas, no nível de cultura da população e uso político da mídia foram outros aspectos analisados pela Escola Funcionalista.

Na teoria funcionalista, o processo de comunicação é explicado pelo Paradigma de Lasswell, tratando da relação entre emissor e receptor, através de analogias biológicas (sociedade como organismo) e elétricas (comunicação como transmissão de sinais). 
A intenção é de contextualizar o processo de comunicação e explicar as condições que 0 possibilitam. Ele se dá numa sociedade de massas, capitalista, liberal, prevalecendo as leis de mercado (oferta e procura). A visão liberal é expressa na fala de Lazarsfeld:

"Os efeitos dos meios de comunicação são limitados, impedindo a sua utilização para fins autoritários. Uma das razões para essa limitação seria a resistência por parte da Opinião Pública: numa sociedade democrática, há pluralidade de fontes para ajudar a formar a opinião do público, impedindo uma visão hegemônica e interferindo nos processos sociais". ${ }^{29}$

Formulado em 1948, o modelo de Lasswell procurou descrever o ato comunicativo por meio de seis perguntas: Quem? (emissor), Diz o quê (mensagem), Em que canal? (meio), Para quem? (receptor), Com que efeito? (retroalimentação). ${ }^{30}$

0 modelo de Lasswell é um dos mais conhecidos, entre as tentativas de se estruturar o processo comunicativo e tem, em suas bases, elementos da chamada Teoria Hipodérmica ${ }^{31}$, segundo a qual "cada elemento do público é pessoal e diretamente atingido pela mensagem".

Há uma confluência temporal entre essa teoria comunicacional e o período entre as duas grandes guerras mundiais. Também entre as décadas de 20 e 50 do século XX

\footnotetext{
${ }^{29}$ LAZARSFELD, P. in: SANTOS, R. Introdução à teoria da Comunicação, São Bernardo do Campo, Editora Bartira, 1992, pág. 14

${ }^{30}$ Idem, pág 14.

${ }^{31}$ WOLF, M. Teorias da Comunicação, Lisboa, Editorial Presença, 1995. Pág. 20-21.
} 
aconteceu o desenvolvimento das chamadas comunicações de massa - cinema, rádio e televisão. Esse fato ajudou na consolidação dessa teoria como modelo a ser seguido na pesquisa em Comunicação nas décadas subseqüentes.

Assim, de acordo com Lasswell, as palavras chave poderiam estar definidas nos termos persuasão, já que para ele, a comunicação desempenha as funções de vigilância, correlação e transmissão cultural. ${ }^{32}$ Esse modelo - talvez inspirado nos estudos desenvolvidos por Claude Lévi-Strauss no início do século XX - formaliza a estrutura e estuda o processo comunicativo a partir da decomposição da mensagem e da análise dos seus componentes.

A fórmula de Lasswell possui uma estreita ligação com o outro modelo comunicativo, o da Teoria da Informação, de Shannon e Weaver. A base dessa teoria, também chamada de teoria matemática da comunicação, é a quantidade (taxa) de informação existente num processo comunicacional.

"Sua origem está ligada a estudos estatísticos das transmissões telefônicas e telegráficas. A intenção desses estudos era eliminar os ruídos (problemas nas transmissões) nos canais físicos, através de seleção e discriminação de signos para estabelecer mensagens mais econômicas e precisas" ${ }^{33}$.

\footnotetext{
32 LASSWELL, H. in: GOMES, P. Tópicos de Teoria da Comunicação, São Leopoldo, editora Unisinos, 2001. P. 33.

33 SANTOS, R. Introdução à teoria da Comunicação, São Bernardo do Campo, Editora Bartira, 1992, pág. 23-24
} 
Para garantir o caráter informativo das mensagens e, assim, assegurar a comunicação, a teoria da informação faz uso da redundância (excesso de sinais), seja pela escolha do código (sistema de símbolos para representação das mensagens), mais eficiente.

Utilizando-se de estudos da Física, a teoria da informação relaciona o conceito de entropia (medida do grau de desordem e incerteza de um sistema) com o nível de informação. O primeiro representa o grau de confusão no sistema, enquanto o segundo procura reduzir as incertezas.

No entanto, quanto mais original ou inesperada uma mensagem, maior o nível de informação recebido. Já a redundância aumenta a previsibilidade de uma mensagem, mas assegura que ela seja recebida pelo destinatário.

Ou seja, é uma relação custo/benefício envolvendo a redundância em relação ao nível de informação propagado dentro do sistema. 0 nível de certeza do receptor depende do conteúdo da mensagem, do uso correto do canal e do código empregado e da eficiência do sistema. Este último tem como objetivo medir a quantidade de informação transmitida no canal comunicativo e aferir a eficiência do processo. É uma visão quantitativa da Comunicação.

Se, no caso da Teoria da Informação, a preocupação está centrada na eficiência do canal - conforme exposto no parágrafo acima - para Lasswell, a problemática está nas 
mensagens e em seus efeitos sobre os receptores do processo de Comunicação. Os dois modelos se caracterizam pela unidirecionalidade, a definição de papéis, o congelamento e simplificação do processo.

Trata-se de uma teoria funcionalista, na qual o conjunto das funções relaciona-se num todo. A sociedade é vista como um organismo e cada órgão dá sua contribuição para o funcionamento do sistema.

Essa sistematização teórica proposta por Lasswell fundamentou estudos sociológicos, antropológicos e administrativos, envolvendo autores como Robert Merton e Wilbur Schramm, este último, autor do livro Processos e Efeitos da Comunicação de Massa, no qual trouxe para a estrutura anterior os componentes denominados por Scharamm como "codificador" e "decodificador". ${ }^{34}$

Weaver e Shannon ${ }^{35}$, em "A Teoria Matemática da Comunicação' abordam a teoria da Comunicação, sob uma ótica linear. Vindos das ciências exatas, esses pesquisadores não estão preocupados com o sentido da mensagem. Para a dupla de engenheiros, o foco do processo comunicacional está na informação.

Assim, eles conceberam um sistema geral de comunicação composto por cinco tópicos: fonte de informação, transmissor, canal, receptor e destinatário. Weaver, descrevendo

\footnotetext{
${ }^{34}$ GOMES, P. Tópicos de Teoria da Comunicação, São Leopoldo, editora Unisinos, 2001, pág. 34-35.

${ }^{35}$ WEAVER, W. e SHANNON, C, “A Teoria Matemática da Comunicação”. In: COHN, G. (org). Comunicação e indústria cultural. São Paulo: Cia. Editora Nacional, 1978.
} 
trabalho realizado por Shannon, apresenta a seguinte representação de um sistema de comunicação: Fonte de informação $\Rightarrow$ Transmissor $\Rightarrow$ Canal $\Rightarrow$ Receptor $\Rightarrow$ Destino.

A principal crítica a se fazer aos dois modelos funcionalistas é a rigidez na percepção do fenômeno comunicacional e a visão puramente quantitativa nos dois modelos. Fica difícil saber como eles seriam úteis para entender o surgimento de ferramentas como a wikipedia e os blogs. Ambas as ferramentas, criadas com o desenvolvimento do Jornalismo digital, têm como pressuposto um processo não-linear de criação e edição das informações e das notícias.

De qualquer maneira, essas teorias tiveram papel relevante na fundamentação da teoria da Comunicação, especialmente pela criação de termos utilizados até hoje em nossos trabalhos: fonte, receptor, emissor, transmissão e canal. 


\section{2 - A ESCOLA DE FRANKFURT}

0 contraponto às teorias da Escola Funcionalista surgiu na Alemanha dos anos 30. Pesquisadores do Instituto de Pesquisa Social - Theodor Adorno, Max Horkheimer, Herbert Marcuse e Walter Benjamin, dentre outros - não eram originários do campo da Comunicação. Em sua maioria, eram filósofos, e tinham em comum um projeto de crítica da sociedade.

A Escola de Frankfurt - como ficou vulgarmente conhecida essa corrente teórica - tinha um espectro de preocupações que incluía as mudanças trazidas pelas novas técnicas (rádio, cinema e imprensa escrita) em vários aspectos da existência humana: as Artes, a Política e também a Comunicação. Com ênfase na importância dos fenômenos de mídia no mundo contemporâneo.

Por isso, a recusa desses pesquisadores em aceitar que os fenômenos comunicacionais pudessem ser estudados de forma isolada. A intenção dos pensadores frankfurtianos era esclarecer as realidades surgidas com o desenvolvimento do capitalismo industrial no século $X X$.

Ou seja, as teorias da Escola de Frankfurt tinham um forte viés político. Sua matriz teórica predominante eram as teses marxistas e a crítica ao capitalismo. Além disso, se apoiavam nas idéias de Nietzsche e Freud para analisar a sociedade nascente devido às mudanças causadas pelo capitalismo. 
Adorno e Horkheimer criaram dois conceitos fundamentais para a análise de mídia que seria feita posteriormente: Dialética do Esclarecimento e Indústria Cultural. 0 primeiro criticava a idéia iluminista "da libertação do homem por meio do uso da razão e que a tecnologia levaria à sociedade a um estágio superior." ${ }^{36}$ Ou seja, pode-se dizer que essa corrente é fortemente contrária às idéias de positivismo e progresso, como pensava a sociologia francesa do século XIX.

Já o conceito de Indústria Cultural trata da produção em série e da homogeneização da produção cultural. A conseqüência mais perversa do fenômeno da exploração comercial da cultura "é a deteriorização dos padrões culturais".

Segundo Adorno e Horkheimer, "a máquina da indústria cultural, ao preferir a eficácia dos seus produtos, determina o consumo e exclui tudo o que é novo, tudo o que se configura como risco inútil”. ${ }^{37}$ Outra conseqüência é a dominação do sistema por meio das técnicas, gerando uma sociedade passiva e pouco afeita a mudanças ${ }^{38}$.

Apesar disso, alguns integrantes da Escola de Frankfurt simpatizaram com as mudanças tecnológicas a despeito de repudiar a cultura burguesa. Benjamin acreditava que a máquina e o modo de vida urbano estavam criando um novo horizonte cultural e mesmo uma nova estética.

\footnotetext{
${ }^{36}$ SANTOS, R. Introdução à teoria da Comunicação, São Bernardo do Campo, Editora Bartira, 1992, pág. 15.

${ }^{37}$ ADORNO e HORKHEIMER. A Indústria Cultural. “O Iluminismo como mistificação das massas”, in Lima, Luiz Costa. Teoria da Cultura de Massa. Paz e Terra, RJ, 1978. P. 158-204.

38 SANTOS, R. Introdução à teoria da Comunicação, São Bernardo do Campo, Editora Bartira, 1992, pág. 16.
} 
O ensaio "A obra de arte na era de sua reprodutibilidade técnica" condensa as principais idéias de Benjamin. Segundo ele, o capitalismo democratizou os meios de produção artística, por trazer uma experiência estética em meios extra-estéticos (rádio, cinema e outras tecnologias posteriores).

Mas há um preço a ser pago com os avanços tecnológicos. A obra de arte possuía uma dimensão de culto, dado o seu caráter artesanal e único. A associação do artista ao gênio só fez reforçar essa tese, durante o século XIX. Mas a reprodução massiva das obras de arte banalizou a produção cultural: é a perda da aura, segundo Benjamin.

O fenômeno consiste em produzir ou adaptar a arte segundo um padrão de gosto bem sucedido e desenvolver técnicas para mercantilizá-la. Ou seja, a produção cultural e artística passa a ser vistam em função da possibilidade de consumo dessas obras.

Além disso, há empecilhos na relação entre público e artista: com a mercantilização, ela agora é realizada por produtores e outros técnicos. A arte é marcada pela ideologia dominante e uma sociedade conformista é o resultado dessa produção cultural massificada, criticam os pensadores de Frankfurt.

O ponto a ser salientado, segundo os pensadores desta vertente teórica é que, dentro da lógica da indústria cultural as mensagens têm uma lógica de produção e de distribuição similar às demais mercadorias, dentro de um sistema econômico capitalista. 
Para os filósofos da Escola de Frankfurt,

"Os produtos culturais, os filmes, os programas radiofônicos, as revistas ilustram a mesma racionalidade técnica, o mesmo esquema de organização e de planejamento administrativo que a fabricação de automóveis em série ou os projetos de urbanismo. Cada setor da produção é uniformizado e todos os são em relação aos outros" (...) "A indústria cultural fornece por toda parte bens padronizados para satisfazer às numerosas demandas, identificadas como distinções às quais os padrões da produção devem corresponder" 39 .

Jurgen Habermas, filósofo alemão e herdeiro dessa corrente teórica, desenvolveu suas próprias teorias sobre a Comunicação e a esfera pública no livro "A Técnica $\boldsymbol{e} \boldsymbol{a}$ ciência como ideologia (1968) e também na obra "Teoria da ação comunicativa " (1971). Para Adorno e Horkheimer, todo o potencial emancipatório da ciência está voltado para a reprodução do sistema de dominação e sujeição.

Já Habermas reflete sobre a alternativa à degenerescência do político, do qual o Estadosujeito se faz agente, reduzindo os problemas a seu aspecto técnico, derivado de uma administração racional. A solução, segundo ele, encontra-se na restauração das formas de comunicação num espaço público estendido ao conjunto da sociedade. ${ }^{40}$

\footnotetext{
${ }^{39}$ MATTELART, Armand e Michele. História das Teorias da Comunicação. Loyola, São Paulo, 1999. P. 76-77.

${ }^{40}$ Idem. P. 83.
} 
As teorias e hipóteses defendidas pelos frankfurtianos tiveram sua importância dentro de um determinado contexto histórico, o da Guerra Fria. Com a disputa entre os sistemas capitalista e socialista de produção, era necessário entender as implicações sociais e econômicas da produção e veiculação de notícias.

No entanto, assim como a teoria rival funcionalista de cunho liberal, as teorias aventadas pela Escola de Frankfurt não levariam em consideração as transformações propiciadas pela sociedade em rede - parafraseando Castells.

A mídia hoje não é mais unidirecional, é produzida em plataformas tecnológicas propiciadoras de mais interatividade e velocidade. Considerar todas essas transformações constituiria um viés importante para pesquisar o J ornalismo como ele se apresenta no mundo atual. 


\section{3 - ESTUDOS CULTURAIS E LINGUAGEM}

Uma terceira via de análise do campo da Comunicação são os chamados Estudos Culturais. Essa corrente teórica surgiu na Inglaterra durante os anos 60 do século XX para analisar as mudanças nos valores da classe operária inglesa. A intenção desses pesquisadores era demarcar quais as mudanças acontecidas na relação entre a cultura e a sociedade.

O foco dessas pesquisas consiste na coleta de materiais culturais pouco valorizados, como a cultura popular, e analisá-los de modo qualitativo. 0 objetivo é mostrar que as massas não precisam estar em posição subalterna no tocante a cultura. Pelo contrário, essa cultura popular pode ser uma forma de resistência à dominação exercida pelas classes mais abastadas ou mais elitistas dentro do estrato social.

Assim como aconteceu com a produção teórica da Escola de Frankfurt, os pesquisadores dessa vertente - Thompson, Williams e Stuart Hall - não tiveram uma ação coordenada entre si.

Mas há características comuns aos pesquisadores culturalistas: procura por padrões de idéias e comportamentos; análise das formas textuais e documentais de um grupo social; cultura popular como o objeto de estudo principal. 
Um segundo ponto de aproximação com a Teoria Crítica é a visão não homogeneizada e monolítica de cultura. Para esses pesquisadores, a cultura é a manifestação de uma formação social ou de um período histórico. Por conseguinte, ela não é vista como a transmissão passiva de uma sabedoria, mas intervenção ativa tanto para transmitir o passado ou para criar perspectivas futuras.

Mesmo guardando certa inspiração marxista, os Estudos Culturais criticam a visão reducionista e economicista que serve de base aos pensadores de Frankfurt. Segundo os culturalistas, a produção artística sofre influência não só da Economia, mas também da Política, da Antropologia e de outros campos. O cruzamento de todas essas influências explicaria a complexidade do mundo em que vivemos, dizem eles.

\section{Ciências da Linguagem}

Também há uma contribuição vinda do campo das chamadas Ciências da Linguagem. Esse campo do conhecimento analisa a Comunicação e o Jornalismo enquanto representação e simbolização do mundo exterior à Linguagem. Nesse sentido, o Jornalismo aparece como o articulador do discurso dos diversos atores sociais.

“A comunicação pode e deve ser vista e analisada desde um paradigma dado pela semiótica, que possui a sua raiz na lingüística (...). Quem primeiro intuiu que os métodos lingüísticos poderiam ser aplicados a outras formas de comunicação, lançando o projeto de uma nova teoria dos signos, que designou como semiologia, foi Ferdinand 
Saussure". ${ }^{41}$ O lingüista francês dedicou-se à linguagem e à relação entre um signo ( a palavra) e os outros signos.

A Semiótica entende a mensagem como um conjunto de signos e o processo de comunicação como um processo de significação, como um processo portador de sentido. É a partir de 1964 que Roland Barthes vai definir uma metodologia específica que vai além dos modelos da língua. ${ }^{42}$

Barthes definiu a semiologia como tendo por objeto qualquer sistema de signos, sejam quais forem a sua substância ou os seus limites: as imagens, os gestos, os sons e a complexidade que encontramos nos ritos, protocolos ou espetáculos que constituem senão linguagens, ao menos sistemas de significação.

A Semiologia constitui um "campo autônomo de estudos, composto por diversas perspectivas, que se desenvolvem de forma paralela à Teoria da Comunicação. Por si só, ela representa um complexo âmbito de estudos que não se preocupam nem com o processo comunicativo como tal ou com a relação comunicação-sociedade; o centro da preocupação é a mensagem". ${ }^{43}$

\footnotetext{
${ }^{41}$ GOMES, P. Tópicos de Teoria da Comunicação, editora Unisinos, São Leopoldo, RS, 2001, p. 39-40.

${ }^{42}$ RODRIGUES, D, p. 45-47, citado em GOMES, P. Tópicos de Teoria da Comunicação, editora Unisinos, São Leopoldo, 2001, p. 40-41.

${ }^{43}$ ARAÚJO, Carlos Alberto Ávila. Segundo capítulo da monografia “O modelo comunicativo da Teoria do Jornalismo”, apresentada como trabalho de conclusão de curso junto ao Departamento de Comunicação Social da FAFICH/UFMG, 1996.
} 
Para Peirce, a Semiótica - ou doutrina geral dos signos, se constitui em três níveis, distintos: sintático (signos e suas relações com outros signos); semântico (signos e suas relações com o "mundo exterior"), e pragmático (signos e suas relações com os "usadores"). ${ }^{44}$

Já Wolf ${ }^{45}$, entende que existem dois modelos: o semiótico-informacional e o semióticotextual -, elaborados por Eco e Fabbri. O primeiro seria a apreensão do fenômeno comunicativo enquanto um processo de transmissão linear vinculada ao funcionamento dos fatores semânticos introduzidos mediante o conceito de código. A informação não seria mais transmitida de um emissor para um receptor, mas transformada de um sistema para outro, através do código.

O outro modelo, também de Eco e Fabbri, o semiótico-textual, apresenta-se como uma contribuição mais aberta da Semiótica, rejeitando a idéia de linearidade e propondo a noção de rede textual.

No entanto, vale destacar que as análises semióticas e semiológicas não são estudos sobre o processo comunicativo, mas apenas sobre um de seus elementos - a mensagem. Mas é forçoso reconhecer que o desenvolvimento dessa vertente de estudo trouxe um grande avanço para a Teoria da Comunicação: "a identificação do ato

\footnotetext{
${ }^{44}$ CHAIM, S, DORIA, F e LIMA, L. Dicionário Básico de Comunicação. Editora Paz e Terra, segunda edição, RJ, 1975. P. 376-377.

${ }^{45}$ WOLF, M. Teorias da Comunicação. Presença Editorial, Lisboa, 1987, p 109.
} 
comunicativo enquanto processo de significação, e não apenas como um fenômeno transmissivo, linear." ${ }^{46}$

\footnotetext{
${ }^{46}$ ARAÚJO, Carlos Alberto. Segundo capítulo da monografia “O modelo comunicativo da Teoria do Jornalismo”, apresentada como trabalho de conclusão de curso junto ao Departamento de Comunicação Social da FAFICH/UFMG, MG, 1996.
} 


\section{4 - A EPISTEMOLOGIA DA COMUNI CAÇÃO}

A discussão sobre o status epistemológico da Comunicação aconteceu simultaneamente aos estudos sobre o campo e o objeto comunicacional. Esse debate sobre os conhecimentos gerados pela Comunicação e a metodologia adequada para estudá-los estende-se também à área de J ornalismo. 0 jornalismo é uma Ciência? É somente uma técnica?

Há a necessidade de estudar os impactos das mudanças tecnológicas no modus operandi do J ornalismo por causa do surgimento de novas ferramentas utilizadas pelos jornalistas, - mecanismos de busca, blogs, wikis e outras ferramentas colaborativas.

Muniz Sodré, teórico brasileiro da Comunicação, propõe uma revisão teórica nesse campo em vista dessas transformações causadas pelas transformações recentes nas mídias $^{47}$. José Marques de Melo, pesquisador do Jornalismo, também aponta para a necessidade de um novo aporte teórico:

"Enquanto objeto de estudo, a Comunicação tem sido alvo de interesse de inúmeras disciplinas científicas, que a refletem teoricamente e a analisam empiricamente, a partir dos seus respectivos paradigmas. Mas enquanto campo acadêmico, sua identidade tem se caracterizado pelo delineamento de fronteiras, estabelecidas em função dos suportes

\footnotetext{
${ }^{47}$ Cf. Ciberlegenda, no 03, 2001, http://www.uff.br/mestcii/muniz1.htm
} 
tecnológicos (mídia) que asseguram a difusão dos bens simbólicos e do universo populacional a que se destinam (comunidades/coletividades)". ${ }^{48}$

Martino é outro pesquisador a reclamar uma maior especificidade epistemológica para a Comunicação:

“De um lado, a Comunicação aparece como um saber que vem perdendo, ou que já perdeu um estatuto científico, se é que já teve algum dia. De outro lado, tudo parece indicar que ela nunca foi e nunca será uma ciência. Mas entre a negação que nos alcança do passado e aquela outra que se estende do presente para o futuro, é preciso abrir um caminho, como condição necessária para que a reflexão venha se instaurar. Em outros termos, antes de abandonar um projeto do qual nem mesmo temos certeza de que tenha sido formulado (por acaso alguém teria reivindicado a fundação de uma ‘Ciência da Comunicação'?), não seria conveniente examiná-lo com a seriedade e o cuidado que merece?" 49

Há mais uma preocupação nessa discussão sobre o status epistemológico da Comunicação e a necessidade de uma nova perspectiva metodológica e teórica para o Jornalismo: mudaram as plataformas de criação, edição, publicação e veiculação das notícias.

\footnotetext{
${ }^{48}$ MELO, J. “Ensino de Graduação em Comunicação Social: paradigmas curriculares”.Revista Brasileira de Ciências da Comunicação, Identidades Comunicacionais, ano XXI, número 01, janeiro/Juno de 1998, Intercom, São Paulo. Pág. 17-18.

49 MARTINO, L. “As epistemologias Contemporâneas e o Lugar da Comunicação”, in Lopes, Maria Immacolata Vassalo de (org), Epistemologia da Comunicação, São Paulo, Loyola, 2003. P.100.
} 
A relação com o leitor também mudou a partir do advento das novas tecnologias: há mais velocidade nessa interação. Sem falar que, hoje, o jornalista não é mais a única fonte de produção de notícias. 0 autor norte-americano Dan Gillmour chama a atenção para esse último fato no livro We, the media. ${ }^{50}$

Nessa linha de pensamento, autores e trabalhos voltados para a autopoiese e a autoorganização (Varella ${ }^{51}$ e Prigogine ${ }^{52}$, entre outros) dão destaque para conceitos como entropia, leis da termodinâmica e sistemas dissipativos, vindos das ciências exatas e biológicas. Essas teorias fundamentam as idéias de autores como Henn ${ }^{53}$, que estuda a relação entre sistemas caóticos e J ornalismo.

Antes de Varela e Progogine, é bom lembrar, Norbert Wiener, teórico da Comunicação filiado à vertente da cibernética, já abordava o conceito de retroalimentação no processo comunicativo:

“O propósito da cibernética é o de desenvolver uma linguagem e técnicas que nos capacitem, de fato, a haver-nos com o problema do controle e da comunicação em geral, e descobrir o repertório de técnicas e idéias adequadas para classificar-Ihe as manifestações específicas sob a rubrica de certos conceitos (...) A minha tese é a de que o funcionamento físico do indivíduo vivo e o de algumas máquinas de comunicação mais

\footnotetext{
${ }^{50}$ GILLMOR, D. We the Media: Grassroots Journalism By the People, For the People. Oreilly \& Assoc, 2004.

${ }^{51}$ VARELA, F. “Le cercle créatif”. In: Watzlawick, 1988.

${ }^{52}$ PRIOGINE, I. \& Stengers, I. La nouvelle alliance. Paris, Gallimard, 1986.

${ }^{53}$ HENN, Ronaldo. Os Fluxos da Notícia, uma semiose sistêmica, São Leopoldo, editora Unisinos, 2002.
} 
recentes são exatamente paralelos no esforço análogo de dominar a entropia através da realimentação". 54

Ainda no período compreendido nas décadas de 1950 a 1970, outra corrente teórica ganhou destaque: a teoria dos sistemas - o conjunto das funções relaciona-se num todo - ganha destaque. Nessa visão, os pesquisadores buscam compreender a relação dos estados de um elemento particular do sistema em função do todo e vice-versa.

Mais recentemente, dois biólogos chilenos, Humberto Maturana e Francisco Varella, refutam essa concepção de sistema aberto, desenvolvendo a idéia de autopoiesis e de sistema autopoiético (do grego autos, "si mesmo", e poisen, "produzir"). Com Varella e Maturana, vem à tona o conceito de emergência com maior intensidade. Para eles:

“um sistema autopoiético organiza-se como uma rede de processos de produção cujos componentes regeneram continuamente por suas transformações e interações a rede que os produziu; e constituem o sistema como unidade concreta no espaço em que ele existe, especificando o domínio topológico no qual se realiza como rede (...). O específico de nossa atividade cotidiana é o fazer emergir". ${ }^{55}$

Esta linha de pensamento vem ganhando espaço nos estudos voltados à comunicação, especialmente com a chegada da "rede das redes", a Internet. Trabalhos mais recentes

\footnotetext{
${ }^{54}$ WIENER, Norbert. Cibernética e Sociedade - O Uso Humano de seres humanos, São Paulo, Cultrix, 1954.

${ }^{55}$ MATTERLART, Armand e Michele. História das Teorias da Comunicação. São Paulo, Loyola, 1999. Pág. 163.
} 
abordam a questão, utilizando a terminologia desta corrente, especialmente o conceito de emergência:

“A aprendizagem também será um tipo de emergência, uma ordem de alto nível, formando-se a partir de componentes relativamente simples (...).A Teoria Matemática da Comunicação continha uma elegante introdução, em linguagem para leigos, à teoria de Shannon, escrita pelo cientista Warren Weaver (...). O documento que Weaver produziu, em muitos aspectos, merece ser visto como o fundador da teoria da complexidade". ${ }^{56}$

A quantidade de teorias poderia sugerir a existência de um conhecimento consolidado no campo da Comunicação. Ou ainda, que haveria muitas formulações teóricas para entender 0 processo comunicacional. No entanto, vários autores salientam a necessidade de mais estudos acadêmicos sobre a Comunicação. Vejamos:

Wolton ${ }^{57}$ tenta compreender a falta de demanda de conhecimento no setor, salientando que "os efeitos devastadores de uma desvalorização da comunicação, reduzida a um processo técnico e a um estatuto teórico de segunda ordem". Para o autor há algumas razões para "não querer saber mais" sobre a Comunicação, de um modo geral. Wolton enumera alguns tópicos para explicar esse descaso:

\footnotetext{
${ }^{56}$ JOHNSON, Steven. Emergência, a Dinâmica de Rede em Formigas, Cérebros, cidades e softwares, Rio de Janeiro, Jorge Zahar editor, 2003. Pág. 33-34.

${ }^{57}$ WOLTON, D. Internet, e depois? Uma teoria crítica das novas mídias. Porto Alegre, Editora Sulina, 2003. Pág. 48.
} 
A dificuldade de análise. "Todo processo de comunicação, uma vez que integra as relações entre emissor, mensagem e receptor é complexo. Não existe nenhuma continuidade, nem complementaridade entre estas três lógicas, e a recepção é a mais complicada para se compreender (...)".

Outra razão (sobre a resistência no que diz respeito a um entendimento teórico da Comunicação) diz respeito à vontade de saber sobre estas mutações (técnicas). Para o autor, "ela é menos visível do que há 30 anos, como se o sucesso das novas mídias trouxesse com ele as respostas aos problemas colocados. 'Os mercados responderam', poderia se dizer. Resta realmente algo em que pensar? (...)"

De acordo com Wolton, outra resistência à analisar a Comunicação vem dos meios intelectuais:

"Estes se sentiram erroneamente ameaçados em sua cultura de elite, até em seu papel, com o surgimento das mídias generalistas que, quase automaticamente, mudaram as fronteiras entre cultura de elite, cultura média, cultura de massa e cultura particular. Em todo caso, os meios intelectuais se inquietaram logo que surgiu o rádio nos anos 30, pois acreditaram, desde já, que seria uma ameaça ao livro e ao jornal. 0 silêncio e depois a crítica se instalaram". 
0 autor prossegue em seu questionamento:

"O que fazer para criar um desejo de conhecimento, antes que as crises consecutivas à mundialização da comunicação e sua generalização em todas as esferas da sociedade gerem conflitos? Sem dúvida, marcar o mais nitidamente possivel a diferença entre estudo e pesquisa científica; insistir no fato de que não é mais possivel pensar as tecnologias sem uma problemática mais geral da comunicação; revalorizar as hipóteses que obrigam a pensar além de uma simples descrição; reconhecer que não é fácil, quando os fatos são tão numerosos e ocorrem tão rapidamente, de ter uma ou mais teorias globais; manter-se empírico para ver concretamente o que provém dos usos e costumes; introduzir uma perspectiva histórica e comparativa para escapar da tirania das mudanças atuais". ${ }^{58}$

De acordo com o autor francês, "a performance das técnicas não impede uma reflexão teórica, ela a exige, à medida que as defasagens tornam-se crescentes entre a 'boa' comunicação da tecnologia e a 'má' comunicação dos homens e da sociedade". ${ }^{59}$

Dificuldades epistemológicas encontradas nesse campo levam alguns até a duvidar da existência de uma teoria da Comunicação. Um exemplo dessa posição teórica está exposta no livro "Teorias da Comunicação; Muitas ou poucas?", organizado pelo pesquisador em Comunicação, Luiz Carlos Martino:

\footnotetext{
${ }^{58}$ Idem, idem. P. 48-53.

${ }^{59}$ Idem. Pág. 55.
} 
“Há menos de 60 anos atrás, não havia conforto em usar o termo teoria quando queríamos nos referir à Comunicação. Muitas das teorias que hoje reconhecemos como teorias da Comunicação permaneceram ligadas ao seu campo do conhecimento durante muito tempo e isso é outra dificuldade para o estabelecimento de um campo comunicacional devidamente demarcado. Assim como durante muito tempo essas teorias não foram confrontadas". ${ }^{60}$

Em outras palavras, faltava uma sistematização das teorias da Comunicação para formar a idéia de teoria unificada. A produção do conhecimento e os livros sobre o tema não servem apenas para que profissionais e docentes da área travem contato com essa temática, mas servem também para que haja reconhecimento epistemológico desse campo do saber.

É interessante notar que poucas das obras de teoria da Comunicação pensam a disciplina enquanto um campo autônomo do saber. Essa constatação é um tanto contraditória: propor uma teoria sobre um fenômeno da realidade (a leitura e produção de notícias) e ao mesmo tempo negar a possibilidade de autonomia desse campo do conhecimento.

Uma das possíveis explicações para essa "dispersão" teórica e principalmente, epistemológica estaria na crença sobre a interdisciplinaridade da Comunicação. O fato

\footnotetext{
${ }^{60}$ MARTINO, Luiz C. Martino (org.), Charles R. Berger e Robert T. Craig , Ateliê Editorial , 2007, Pág. 16-17.
} 
de a disciplina representar um "cruzamento" de outros campos estabelecidos faz a Comunicação apresentar um espectro de teorias bastante alargado.

Uma pesquisa sobre o conteúdo dos livros de teoria da Comunicação mostrou alguns dados que vão ao encontro dessas hipóteses: nenhuma teoria está presente em todos os livros; quase dois terços das teorias aparece em apenas uma obra; cada livro apresenta cerca de $2 \%$ das chamadas teorias da Comunicação. ${ }^{61}$

A interdisciplinaridade acaba contribuindo para adiar um debate epistemológico adequado para definir o que é uma teoria da Comunicação e mais grave: definir o que pode ser considerado como teoria. 0 adiamento de um debate sobre epistemologia da Comunicação também dificulta a delimitação do objeto de estudo.

Para resolver o impasse, alguns esperam pela criação de uma teoria geral, uma formulação conciliadora, à maneira da chamada "teoria de tudo" da Física. Ou caso, seja impossível o consenso, afirmar a impossibilidade de definir um corpo teórico comunicacional.

Naturalizar o objeto de estudo pode ser a explicação para a dificuldade em nomear e entender qual deve ser o objeto a ser estudado pelas teorias da Comunicação. Mas é necessário lembrar que um dos requisitos de uma teoria científica é a formulação de

\footnotetext{
${ }^{61}$ Idem, idem. Pág. 21.
} 
hipóteses e estar ciente que mesmo o fenômeno estudado é uma construção do pesquisador.

No entanto, no que se refere à Comunicação, parece natural que coisas totalmente distintas, como J ornalismo e fenômenos midiáticos possam receber a mesma "etiqueta". "Muitos, inclusive, celebram essa confusão epistemológica como prova da riqueza do nosso campo de estudo". ${ }^{62}$

Martino aponta outra falha naquilo que podemos chamar como "construção do campo comunicacional": não há diferenciação entre teorias sobre comunicação e teorias da comunicação. As primeiras são originárias de outras áreas do conhecimento e enxergam a Comunicação em perspectiva. Já as segundas, designam as teorias que transformariam a Comunicação em um saber autônomo, uma disciplina. ${ }^{63}$

As teorias pioneiras, como as de Lazarsfeld (funcionalista) e Horkheimer (teoria crítica), independentemente do pioneirismo não se referem à Comunicação como campo específico. Essas são pesquisas sobre processos comunicacionais, com conhecimentos provenientes de outras disciplinas.

Cumpre também lembrar outro aspecto que define um campo do conhecimento: um apanhado de teorias não é a mesma coisa que uma disciplina específica. Somente com

\footnotetext{
62 Idem, idem. Pág. 27.

${ }^{63}$ Idem, idem. Pág 30-31.
} 
a sistematização do conhecimento há a visão do todo. Com isso, caso haja a chegada de uma nova teoria, os conhecimentos anteriores podem ser alterados, gerando novas condições de pesquisa.

Outro problema enfrentado pelos pesquisadores em Comunicação é a fragmentação do campo. É muito raro ver pesquisadores de universidades diferentes trabalhando num mesmo tema. Ainda que existam coincidências sobre alguns domínios (áreas mais amplas), há pouca chance de intersecção entre as questões específicas a serem investigadas.

Charles Berger ${ }^{64}$ se pergunta sobre qual seria a maneira mais eficaz de criar um conjunto pequeno de questões epistemológicas para orientar os esforços de pesquisa. Congressos, seminários e toda a sorte de eventos acadêmicos podem ajudar nessa fundamentação. Mas isso requer uma massa de pesquisadores trabalhando sobre um tema, neste caso a Comunicação, sublinha o autor.

Em perspectiva oposta, Robert Craig ${ }^{65}$ afirma que a despeito do desenvolvimento acadêmico e do crescente número de trabalhos sobre Comunicação, há mais incerteza, dissensão e controvérsia em relação às formulações teóricas sobre este campo. Paradoxalmente, apesar de estarmos fazendo mais teorização sobre o campo, estamos menos seguros sobre o que estamos ou deveríamos estar fazendo.

\footnotetext{
${ }^{64}$ MARTINO, Luiz C. Martino (org.), Charles R. Berger e Robert T. Craig , Ateliê Editorial , 2007

${ }^{65}$ Idem.
} 
Segundo Craig, uma mudança epistemológica nas ciências humanas explica a "confusão teórica" no campo da Comunicação. Esses problemas de cunho teórico-epistemológico talvez expliquem a dificuldade das teorias da Comunicação e do Jornalismo - o que nos interessa aqui - em dar conta da produção de notícias e do efeito da recepção dessa produção midiática pelo público.

Como podemos observar, numa rápida retomada de alguns trabalhos produzidos na área, a variedade de olhares e os embates na busca de conceitos e metodologia sempre marcaram a pesquisa em Comunicação.

Porém, poucos autores se aprofundaram nesta discussão a ponto de propor modelos epistemológicos e metodológicos eficientes, em especial, para o novo cenário que se apresenta. Mais adiante, veremos que estas bases, conceituais e metodológicas, ficam um tanto mais frágeis quando falamos de pesquisa científica em Jornalismo. 


\section{4 - O J ORNALI SMO ENQUANTO CAMPO DE CONHECI MENTO}

É sabido que há uma trajetória de quatro séculos no ofício jornalístico. A primeira tese a analisar as relações entre as notícias e a sociedade data de 1690, de autoria de Tobias Peucer ${ }^{66}$. Há, portanto, um saber acumulado nesse campo definido hoje como parte das ciências sociais aplicadas. A questão que se coloca é saber qual a metodologia que melhor pode entender e avaliar este campo do conhecimento.

As principais abordagens atuais podem ser divididas, grosso modo, em dois tipos: a vertente lingüística e a vertente funcionalista. A primeira delas vê a comunicação como um discurso institucionalizado, uma manifestação de poder. A segunda estuda os efeitos da comunicação e percebe 0 ato comunicativo enquanto dependente dos meios nos quais ele é veiculado. Ambas têm seus pontos fracos.

Há muito mais componentes envolvidos no Jornalismo enquanto sistema que interage com a sociedade do que um discurso instituído e relações mediadas de causa e efeito entre dois pólos comunicativos. A primeira delas - uma hipótese - é dita acima: o J ornalismo é um sistema que interage com a sociedade.

A segunda é saber como o J ornalismo se institui enquanto foro de discussão e como um sistema com uma dinâmica própria: padrões de produção, escolhas editoriais, mecanismos de fidelização do leitor. E aquelas abordagens, numa análise mais detida,

\footnotetext{
${ }^{66}$ PEUCER, T. Os relatos jornalísticos. Leipzig, 1690.
} 
como pretendemos demonstrar neste trabalho de pesquisa, claramente não dão conta de resolver os problemas aqui colocados.

A alternativa que proponho é analisar estas questões à luz de outra abordagem, a saber: a teoria de sistemas emergentes e de sistemas caóticos. Anda que transportadas de outras ciências, talvez essas teorias nos ajudem a entender essa dinâmica. ${ }^{67}$

É necessário notar a presença de um saber acumulado por quem trabalha e estuda Jornalismo. A dificuldade é criar um saber epistemológico para o Jornalismo e não perceber esse campo do conhecimento somente pelo viés técnico - apropriação de um saber adquirido pela prática.

Para atingir esse status epistemológico seria necessário delimitar campo e objeto de estudo daquilo que chamaríamos de disciplina jornalística. Essa dificuldade é ainda mais agravada com as mudanças tecnológicas trazidas por meios como a Internet e ferramentas de publicação como os blogs.

As inovações tecnológicas trouxeram os componentes da instantaneidade e da resposta imediata do leitor ao produto jornalístico. Mais ainda: uma resposta do leitor pode servir para um aprofundamento da notícia ou até motivar outra cobertura jornalística.

\footnotetext{
${ }^{67}$ MEDITSCH, E., O jornalismo é uma forma de conhecimento? In Media e Jornalismo, $\mathrm{n}^{\mathrm{o}}$ 1, $\mathrm{N}^{\mathrm{o}} 1$, Ano 1 , Florianópolis, 2002.
} 
Com isso, as teorias que já tinham dificuldade em explicar o J ornalismo feito em meios como o papel, ficam cada vez menos eficazes na tentativa de traduzir o que acontece com as mídias no mundo atual. Mais longe ainda está, portanto, a consolidação do J ornalismo como uma disciplina científica.

Uma alternativa para essa problemática seria buscar fundamentação teórica e epistemológica em outros campos do conhecimento científico, como a Física e a Biologia. Outra possibilidade seria a utilização de conceitos criados no estudo da complexidade e na teoria dos sistemas.

A utilização dessas teorias também pode ser uma saída para resolver a questão da objetividade jornalística - uma das dificuldades na aceitação do J ornalismo e mesmo da Comunicação, enquanto disciplinas científicas, é a pretensa falta de objetividade desses dois campos do saber.

A intenção, até aqui, foi a de mapear as principais teorias da Comunicação. Vamos agora focar em algumas teorias do Jornalismo e tentar apontar as principais falhas dessas hipóteses em prever o funcionamento do J ornalismo enquanto campo do saber. Parafraseando o titulo do livro do português Nélson Traquina, é interessante pensar porque "as notícias são como são". 
Nossa idéia é mostrar que o Jornalismo e o modo de produção das notícias mudaram sobremaneira nesses 250 anos de imprensa institucionalizada. Para efeito de comparação, neste mesmo intervalo de tempo, o Capitalismo passou por duas transformações estruturais: começou com o foco nas manufaturas, ganhou as fábricas e hoje faz uso da informática e das tecnologias da informação.

Essas mudanças econômicas e estruturais alteraram a sociedade urbana em que vivemos e alteraram as formas de construção da realidade, da apuração e veiculação das noticias e ainda a relação do publico leitor/consumidor com esses produtos jornalísticos.

Pretendemos introduzir no debate novas teorias para explicar o J ornalismo atual. Essas teorias incorporam conceitos elaborados em outros campos. É o caso da aplicação da lei da entropia - conceito usado inicialmente na área da Termodinâmica - para analisar o J ornalismo, no livro "Os fluxos da notícia' de Ronaldo Henn.

Há autores questionando inclusive se há realmente uma teoria científica sobre o Jornalismo. É a mesma dificuldade encontrada em relação às formulações utilizadas para estudar a Comunicação. Tais dificuldades demonstram que é preciso definir o Jornalismo em termos práticos e também metodológicos. 
Souza aborda algumas questões sobre a pesquisa em Jornalismo, em artigo publicado em 2003:

“Nem todos os pesquisadores do jornalismo estão de acordo sobre um tópico vital: existe ou não um conhecimento científico e reflexivo suficiente para se edificar uma teoria do jornalismo, centrada no processo de produção, circulação e efeitos da informação jornalística? Uma outra questão também tem sido levantada. Podem-se integrar numa única teoria os resultados de pesquisas efetuadas segundo perspectivas diferentes ou até antagônicas?" 68

0 autor português delimita duas áreas "centrais" da "teoria do jornalismo", a da produção da notícia e a da circulação e consumo da notícia (efeitos):

“Uma teoria científica do jornalismo deve procurar integrar diversos fenômenos do campo jornalístico, enfatizando o resultado do processo de produção jornalística - a notícia. Assim, uma teoria do jornalismo deve explicar"(grifo do autor) "as notícias e seus efeitos, qualquer que seja a notícia, o que remete para o caráter de universalidade da ciência. Deve ainda prever como qualquer notícia será construída e quais os efeitos genéricos que gerará (ainda que estes dependam de cada receptor), pois outra das marcas do conhecimento científico é a predição. Para que uma teoria científica seja

\footnotetext{
${ }^{68}$ SOUZA, J. "Por que as notícias são como são? Construindo uma teoria da notícia” in Pauta Geral, Revista de Jornalismo, editora Calandra, Salvador, ano 10, $\mathrm{n}^{\circ}$ 05, 2003. P. 23. O artigo retoma alguns temas abordados em livro do mesmo autor, a saber, As Notícias e os Seus Efeitos - As “Teorias” do Jornalismo e dos Efeitos Sociais dos Media Jornalísticos, editora Minerva/Coimbra, Coleção Comunicação, Coimbra, 2000.
} 
construída, têm de existir dados suficientes para se poder enunciá-la com clareza. Uma teoria científica do jornalismo não pode fugir a esta regra." ${ }^{169}$

Na obra Teoria do Jornalismo - por que as notícias são como são ${ }^{70}$, Traquina analisa o jornalismo - "uma atividade intelectual ${ }^{71 ",}$ que não deve ser reduzida ao domínio técnico de uma linguagem e seus formatos, bem como os jornalistas não devem ser reduzidos "a meros empregados, trabalhadores numa fábrica de notícias".

Pena também adverte para a necessidade de uma teoria específica para o Jornalismo, “conforme as sistematizações propostas por professores como Nelson Traquina, Jorge Pedro Souza, Michael Kunczik, José Marques de Melo e Nilson Lage". ${ }^{2}$ Parafraseando Pena, são duas as perguntas a serem respondidas pela teoria do Jornalismo: Por que as notícias são como são? E quais são os efeitos que estas notícias geram?

Assim, Pena divide as suas preocupações entre produção jornalística e circulação da notícia e efeitos afetivos, cognitivos e comportamentais que incidiriam sobre pessoas, sociedades, culturas e civilizações. Duas instâncias, explica, que de alguma forma se articulam.

\footnotetext{
${ }^{69}$ Idem. P. 24.

70 TRAQUINA, N. Teorias do Jornalismo - porque as notícias são como são, volume I, editora Insular, Florianópolis, 2004.

${ }^{71}$ Idem. P. 22.

${ }^{72}$ PENA, F. Teoria do Jornalismo, São Paulo, editora Contexto, 2005, pág.17.
} 
Na definição de Pena: "Os relatos e reportagens de informações servem à outros membros da comunidade na busca de segurança e a estabilidade do 'conhecimento', a isso, sob certas circunstâncias éticas e estéticas, posso denominar jornalismo". ${ }^{73}$

Nessa discussão sobre o escopo e uma metodologia para estudar Jornalismo, é preciso incluir os usuários das mídias digitais. Os blogs são a plataforma onde jornalistas e outros produtores de conteúdo estão disponibilizando conhecimento sobre diversos assuntos. E tais relatos - para lembrar a definição exposta no parágrafo anterior - não ficam devendo nada aos produzidos por jornalistas profissionais.

No capítulo intitulado Jornalismo Digital, Pena explica que a teoria dos gêneros no jornalismo "ainda encontra dificuldades para definir jornalismo digital". Segundo ele:

"Foi o advento da Internet que possibilitou o novo gênero, e ele veio para revolucionar as relações profissionais e as próprias rotinas produtivas". A partir dessa "unanimidade" afirma que "Jornalismo digital, então, pode ser precariamente definido como a disponibilização de informações jornalísticas em ambiente virtual, o ciberespaço, organizadas de forma hipertextual com potencial multimidiático e interativo". ${ }^{74}$

0 autor reflete sobre algumas das críticas ao jornalismo tradicional ainda pertinentes "no universo on-line, como, por exemplo, a velocidade, a simplificação, a superficialidade e a banalização".

\footnotetext{
${ }^{73}$ Idem, Pág.23.

${ }^{74}$ Idem, Pág. 176.
} 
Características potencializadas pelo Jornalismo Digital, no entender de Pena. Em seu livro, ao final do capítulo de sobre Jornalismo Digital, ele faz a crítica:

"Quando se trata de tecnologia, os conceitos ainda são abordados de forma muito superficial, influenciados pela crença na superioridade ontológica, da técnica sobre a ciência. O conceito de televisão digital, por exemplo, está diretamente ligado ao de convergência tecnológica. E ambos, ao de interatividade. Mas de que interatividade estamos falando? (...) Tudo isso sem levar em conta outras classificações possíveis, que remetem à teoria geral dos sistemas e abordam conceitos como organização, equilíbrio e estrutura, tornando ainda mais complexa a análise sobre interatividade. 0 fato é que, tanto nos círculos acadêmicos como na imprensa, os três conceitos sempre são abordados de forma unificada (...). Como alerta Steve Johnson estamos em um ponto de transição, em que algumas mensagens podem evoluir mais depressa que seu meio. E, ao fazê-lo, antecipam um outro meio, que ainda está em embrião." 75

Kucinski vê aspectos positivos em relação à utilização da Internet como meio de obtenção e veiculação de informações pelos leitores. Ele a associa com as teses de Karl Marx sobre o capitalismo. Segundo o autor: "Ao contrário das teses que denunciam a Internet como um novo mecanismo de exclusão, considero-a um mecanismo de libertação, uma reviravolta nos caminhos até então seguidos pelo capitalismo e uma nova demonstração de que no capitalismo tudo que é sólido se desmancha no ar. ${ }^{76}$

\footnotetext{
${ }^{75}$ Idem. Pág. 182-183.

${ }^{76}$ KUCINSKI, B. Jornalismo na era virtual - ensaios sobre o colapso da razão ética. Editora Unesp, São Paulo, 2005 Pág. 80.
} 
Mesmo tendo sua rede de provedores construída em torno de interesses econômicos dominantes, a Internet, "por sua arquitetura e existência, enfraquece o controle dos aparatos de Estado', diz Castells" ${ }^{77}$ As empresas de jornalismo tradicionais, sejam as de meios impressos ou de meios audiovisuais, aos poucos migram para a Internet. A maior dificuldade está em criar um padrão adequado para esses conteúdos nas mídias digitais. Essa problemática é expressa na fala de Póvoa:

"A maioria das empresas de conteúdo tradicionais estão colocando seus produtos online - revistas, jornais, programas de TV com uma versão web. Muitas dessas empresas simplesmente regurgitam o conteúdo para seu website, o que eventualmente resulta num desastre de comunicação. (...) Fórmulas de produto que já se provaram literalmente eficientes durante décadas podem ser um fracasso completo na web (...) Em suma, papel é papel, vídeo é vídeo, e web é web". ${ }^{78}$

A problemática sobre a melhor maneira de veicular informações e conteúdos em páginas da Internet, exposta no parágrafo acima, está de acordo com as hipóteses levantadas nesse trabalho. Há necessidade de uma nova metodologia de ensino e pesquisa para entender a prática jornalística nos meios digitais. Ferrari é outra pesquisadora da área a atentar para o mesmo problema:

\footnotetext{
${ }^{77}$ CASTELLS, M, autor de A Sociedade em rede. Paz e Terra, São Paulo, 1999, in "Castells adverte que a vida em rede dá força à elite”, O Estado de S. Paulo, São Paulo, 22 fev. 1999, p. D8.

${ }^{78}$ PÓVOA, M. Anatomia da Internet - investigações estratégicas sobre o universo digital. Casa da palavra, Rio de Janeiro, 2000. Pág. 72-74.
} 
“A partir de 2001, o conteúdo jornalístico nos portais foi gradualmente reduzido até 0 ponto de ser fornecido por um grupo restrito de fontes. Com isso os leitores recebem e absorvem a mesma fonte de informação. O que muda é o "empacotamento" da notícia, embora até mesmo os projetos gráficos sejam parecidos uns com os outros". ${ }^{79}$

A autora descreve melhor o processo:

“No caso específico das redações online, a produção de reportagens deixou de ser um item do exercício do jornalismo. Adotou-se apenas a produção de notícias, ou, como se diz no jargão jornalístico, de "empacotamento" da notícia. Empacotar significa receber um material produzido, na maioria das vezes, por uma agência de notícia conveniada, e mudar o título, a abertura, transformar alguns parágrafos em outra matéria para ser usada como link correlato, adicionar foto ou vídeo, e por aí afora. (...)" 80

O Jornalismo precisa buscar construções teóricas que possam delinear melhor alguns conceitos e metodologias de estudo para o Jornalismo Digital. "Verificar as aproximações possíveis entre a pesquisa em jornalismo e as teorias do pensamento complexo pode ser um bom caminho, especialmente adequado às práticas verificadas na web". 81

\footnotetext{
${ }^{79}$ FERRARI, P. Jornalismo Digital. Editora Contexto, São Paulo, 2003. Pág. 18-19.

${ }^{80}$ Idem. Pág. 44-52.

${ }^{81}$ RAMADAN, N. Tese de Livre-docência, "O Jornalismo online visto pelos pesquisadores em São Paulo: a fragilidade das pesquisas que fazem escola (equivocada) nos bancos da graduação", ECA-USP, 2008
} 


\section{1 - MUDANÇAS TECNOLÓGI CAS NO J ORNALI SMO}

Um dos autores mais importantes no estudo da Comunicação é Heinz Von Foerster ${ }^{82}$. As teorias do biólogo austríaco são interessantes para estudar comunicação como um sistema retro-alimentado e com observadores de segunda ordem. Outra idéia introduzida com o pensamento de Von Foerster é a idéia de um observador participante.

A discussão sobre a existência e a percepção da realidade é outro ponto fundamental nas teorias de von Foerster. Segundo ele, essa impressão é construída pelo cérebro, recalculando as sensações tiradas do ambiente e "remontando" o esquema no sistema nervoso do observador. Há possibilidade de analogia para estudar o J ornalismo?

A pergunta se faz pertinente por duas razões: a primeira delas é a necessidade de uma nova metodologia de estudo para fenômenos como os blogs e outras ferramentas colaborativas. Em segundo lugar, porque Von Foerster e todo o Círculo Cibernético americano são oriundos das Ciências Exatas e nem sempre é possível adaptar a metodologia de um campo para outro. A possibilidade e a validade da Comunicação são outros aspectos pesquisados por von Foerster.

Aqui precisamos lembrar da célebre frase do filósofo Ludwig Wittgenstein: só há comunicação quando a ordem é alterada. "Se um soldado obedece ao comandante, não

\footnotetext{
${ }^{82}$ von Foerster, H., Conhecimento e Consciência, (Org. Siegfried J. Schmidt, Frankfurt am Main, Suhrkamp. 1994.
} 
há novidade. Só há chance de Comunicação quando o soldado pergunta: 0 que acontece se eu não obedecer?" 83 .

Podemos então fazer uma ponte com o Jornalismo criado pelas novas tecnologias aqui: o observador participante pode ser um indicador de não há objetividade jornalística no sentido que as ciências exatas a entendem. Uma nova formulação do termo objetividade é necessária para o estudo das ciências humanas.

Não haveria como alcançar objetividade tal como esse conceito é entendido pelas ciências exatas, nesse caso, confundida com a isenção. 0 jornalista carrega consigo toda uma carga cultural e pessoal, impossível de ser dissociada daquilo que ele escreve. A objetividade a ser buscada deve estar no método e não no observador.

O segundo ponto a se observar é justamente essa questão de romper a ordem, lembrando a passagem acima, de autoria do filósofo Ludwig Wittgenstein. Será que há efetivamente comunicação quando um leitor abre o jornal? Nossa hipótese é que haja apenas informação.

É algo unidirecional, de cima para baixo, um sistema hierárquico como as organizações pensavam a informação até o final do século XX. A ausência ou falta de um mecanismo de feedback mais adequado para medir as reações do leitor às notícias é outro problema enfrentado pelos jornais e também pelas teorias que os analisaram até hoje.

\footnotetext{
${ }^{83}$ Idem, pág 347.
} 


\section{Auto-organização}

Retomamos aqui outro autor importante para a discussão sobre complexidade e sistemas auto-organizáveis, o norte-americano Steve Johnson. Há uma tentação enorme em trazer para o estudo do Jornalismo algumas analogias feitas por Johnson no livro Emergência - a dinâmica de rede em formigas, cérebros, cidades e softwares, publicado em 2003.

Johnson utiliza um formigueiro para explicar as principais teorias sobre sistemas autoorganizáveis. Há duas funções básicas desempenhadas pelas formigas: limpeza do formigueiro e busca de comida e as formigas, ao executar essas funções, liberam substâncias diferentes.

Como elas sabem que é o momento de trocar de função? Quando a concentração de uma das substâncias começa a ficar preponderante. É um sistema retro-alimentado e melhor ainda, tende ao equilíbrio, depois de sucessivos feedbacks.

Essa teoria poderia ser aplicada ao estudo de novas mídias? Nossa visão tende a responder essa questão afirmativamente. Aparentemente, um blog pode ser muito mais eficiente do que um jornal para atingir o leitor e principalmente, para saber se o leitor foi efetivamente atingido pela mensagem. 
Há mais possibilidade de saber se o leitor foi atingido pela notícia publicada em um blog quando ele responde na caixa de comentários. É um grau de interatividade jamais imaginado quando pensamos em mídias impressas. Outra possibilidade é a disseminação do link da notícia por e-mail ou que ela seja utilizada por outro jornalista ao escrever uma notícia em momento posterior.

Aqui poderíamos estabelecer uma tentativa de crítica à Escola Funcionalista americana. Eles estavam certos em estudar os efeitos das mensagens. 0 problema é que em 1940 não havia mecanismo eficaz para estudar a recepção e a efetividade do texto dos jornais impressos.

Dessa maneira, o fenômeno poderia ser mais bem avaliado pelo campo da Publicidade. Nesse caso tem como medir: é só acompanhar as vendas. Em outras palavras, é uma boa metodologia, mas foi aplicada para estudar outro objeto. Ainda que parecidos, não dá para estudar J ornalismo, conceitualmente falando, só pelo aspecto comercial. 


\section{Linguagem}

Maturana ${ }^{84}$ diz que a comunicação é impossível por dois motivos: a realidade existe, mas é inapreensível. Em segundo lugar, porque é impossível adquirir conhecimento sobre uma realidade sempre mutante. Quase como um sofista, Maturana joga com uma das características mais perceptíveis das sociedades - e da Comunicação contemporâneas: a velocidade.

Mas discordamos, em parte: só porque um fato acontece muito rapidamente, não significa que eu não possa apreendê-lo. Talvez eu tenha apenas que mudar o meio de apreensão - do jornal para a Internet - ou trabalhar as capacidades cognitivas humanas de maneira diferente.

Maturana apresentaria, de acordo com nossa análise, uma contradição estrutural em sua teoria: tudo o que temos é a linguagem. Da mesma maneira que Berkeley (filósofo inglês do século XVII: Se algo não é percebido, então não existe), ele diz que tudo o que está fora da linguagem não existe.

Mas, como vimos no parágrafo acima, a linguagem é vista somente como forma, e não como o fio que liga os pontos de toda existência humana. Aqui está um dos problemas na concepção teórica de Maturana: a ambigüidade do uso do termo linguagem. Ora como aspecto formal da comunicação humana, ora como o definidor do "humano".

\footnotetext{
${ }^{84}$ MATURANA, H.e VARELA, F. De máquinas e seres vivos. Autopoiese, a Organização do Vivo. Porto Alegre: Artes Médicas, 1997.
} 
Apesar de criticar a tecnocracia, Maturana acaba comungando dela ao pensar uma linguagem que abarque todas as dimensões humanas. Na tentativa de fugir do subjetivismo, que também cerca a Comunicação e o Jornalismo, Maturana tenta desenvolver a linguagem perfeita.

Mas isso é utópico demais. Efetivamente, o meio altera. É inútil negar que as interações com outros seres - ainda mais quando pensamos nas relações entre seres humanos - e as relações com o meio são significativas. Maturana abdica da metacomunicação e esse dilema será resolvido por Gregory Bateson ${ }^{85}$, pesquisador inglês e estudioso da Comunicação em nível mais pessoal.

Bateson percebe a Comunicação como um campo mais analógico do que digital. Seria esse o motivo da dificuldade da transposição de conteúdos do jornal para a Internet? Isso explicaria também a dificuldade de se expressar tão bem por e-mail do que numa conversa olho no olho?

Resumindo, importaria mais a metacomunicação do que a mensagem em si. Aparentemente, é a junção de algumas teorias da Psicologia com a idéia de que o "meio é a mensagem" de McLuhan ${ }^{86}$. Para Bateson, a Comunicação é um processo caótico e destinado à criar ruídos e redundâncias. Num caso extremo, poderíamos fazer uma analogia entre essas falhas comunicacionais e a esquizofrenia.

\footnotetext{
${ }^{85}$ BATESON, G. Steps to an Ecology of Mind. Chicago e Londres, The University of Chicago Press, 2000. Edição original 1972.

${ }^{86}$ MCLUHAN, Marshall. Os meios de comunicação como extensões do homem. São Paulo: Cultrix, 1974
} 


\section{Problemas das novas tecnologias}

Por mais que haja entusiasmo com as novas tecnologias e seja importante tentar descobrir uma teoria sobre a produção de conhecimento e conteúdos dos jornais on-line e blogs, esses novos meios de comunicação e veiculação de notícias também apresentam falhas. Existem algumas ponderações a serem feitas sobre o impacto das novas tecnologias na produção jornalística.

Apenas a geração que nasceu de 1980 para cá é alfabetizada digitalmente. As outras gerações ainda estão se adaptando e elas respondem por pelo menos metade da audiência. A grande questão é como tornar os processos feitos no computador tão intuitivos como eles eram antes do advento da digitalização das mídias.

O ponto em questão é a transformação das mídias. O papel dos editores ficará cada vez mais reforçado. Com 10 bilhões de páginas web, o usuário sente-se oprimido diante de tanto conteúdo. Para isso há dezenas de RSS, feeds e agregadores de notícias. A maior dificuldade é saber como gerenciar tanta informação.

São mudanças que impactam demais a profissão. Um jornalista hoje precisa ser polivalente - e isto é diferente de ser multimídia. Multimídia é um fotógrafo que manda sua imagem para diferentes meios. Polivalente é quem escreve, edita, filma, fotografa e apresenta um telejornal. 
Mas há riscos inerentes à digitalização e transformação da mídia. Para o intelectual inglês Andrew Keen, a Web 2.0 é o culto do amador - justamente por causa das idéias expostas acima. Teremos cada vez mais conteúdo feito por gente que faz "tudo", mas não é um profissional de mídia. Um exemplo desse possível rumo do Jornalismo são as editorias "Minha notícia" no portal iG e Você no Estadão, da versão digital do jornal o Estado de São Paulo. O temor de Keen é que haja um empobrecimento cada vez maior do conteúdo:

“A dimensão participativa da internet diluiu as linhas divisórias entre fato e ficção, entre invenção e realidade, obscurecendo o princípio da objetividade. A criação generalizada em rede se trata de um culto ao amadorismo (...) (...) O resultado? 0 declínio da credibilidade e da qualidade da informação que recebemos". ${ }^{87}$

Em palestra proferida na ECA no dia 11 de fevereiro de 2008, a Professora Charo Sadaba, da Faculdade de Comunicação da Universidade de Navarra alertou: "As redes sociais e outras ferramentas colaborativas baseadas na Web 2.0 vieram mesmo para ficar, mas há uma certa febre nisto tudo".

Nosso ponto é que a tecnologia muda, as pessoas... nem tanto. As tecnologias devem agregar valor e principalmente, facilitar tarefas que já fazíamos de modo analógico. Aqui há uma ligação com o conceito de affordance ${ }^{88}$, criado pelo psicólogo norte-americano James Gibson. É a capacidade de uma interface do computador conseguir imitar

\footnotetext{
${ }^{87}$ KEEN, A. O culto do amador - como a internet está matando a nossa cultura. Nova York, 2007.

${ }^{88}$ Cf. http://pt.wikipedia.org/wiki/Affordance
} 
situações do dia a dia. Esse conceito será utilizado por estudiosos de usabilidade, como Donald Norman. ${ }^{89}$

Porque o YouTube ${ }^{90}$ e o Google ${ }^{91}$ são sites com boa navegabilidade? Porque são simples. No caso do buscador, só existe um lugar onde se pode escrever. O resto é "clicável". No YouTube, o conceito é tomado de forma ainda mais aprofundada. Os comandos imitam um aparelho de som. Estão presentes os botões de Volume, play, forward, reward e stop. Ou seja, a pessoa tem uma reminiscência do aparelho de som e assim, usa o serviço mais facilmente.

No webdesign - e no Jornalismo digital - tudo parece indicar que o conteúdo deve se conformar ao usuário. Por quê os jornalistas devem se arrogar o direito de decidir como e o que deve ser veiculado? Voltamos ao ponto de partida: é possível que o J ornalismo feito em blogs e na Internet tenha conteúdo de valor? Quais teorias devem ser usadas para entender tudo isto?

\section{Dialética e caos}

Ainda que se oponham à escola funcionalista americana, os pensadores frankfurtianos parecem dentro da mesma lógica, com o esquema emissor-canal-receptor. A principal contribuição desses teóricos foi desvendar o mecanismo de reprodução do capitalismo dentro da Indústria Cultural.

\footnotetext{
${ }^{89}$ NORMAN, D. O Design do Dia-a-dia. Rocco, 2006.

${ }^{90}$ http://www.youtube.com

${ }^{91}$ http://www.google.com
} 
Embora alguns estudos mais recentes retomem a Teoria Crítica para compreender a Comunicação na contemporaneidade ${ }^{92}$, sob a nossa perspectiva, isso não basta para entender a Comunicação e o Jornalismo praticado nos dias atuais. É preciso propor e criar alternativas teóricas para compreender esses campos do conhecimento.

Uma alternativa podem ser as teorias de Michel Serres. Serres crê numa desordem criativa, um desvio no Universo, fazendo a analogia do pião. Ainda que ele esteja rodando (a desordem), ele está parado (o Universo é uno).

É interessante para pensar o Jornalismo então como uma relação entre o conteúdo (dinâmico) e a forma (um tanto mais estática). Ou na relação entre o produtor e o receptor dos produtos midiáticos. 0 idioma inglês tem um bom neologismo para isso: é o WReader (escritor e leitor ao mesmo tempo).

Serres critica Maturana de modo feroz: o chileno estaria preso na Filosofia da Linguagem. Para Serres, existe um mundo independente do observador, mas com uma concessão à von Foerster: ele é fabricado e escreve-se a si mesmo.

O que dizer do comentário num blog e da réplica do jornalista autor do post? Ou seja, há três ocorrências de comunicação: o post, a resposta e a tréplica do autor. Como quer Serres, há dinamismo e melhor, há reatividade nesse caso.

\footnotetext{
${ }^{92}$ CÔNSOLO FILHO, S. A comunicação contemporânea e o Jornalismo na web: análise dos portais UOL e Estadão.com em um mundo mercadológico. Dissertação de Mestrado, Faculdade Cásper Líbero, São Paulo, junho de 2009.
} 
Só há a tréplica porque o leitor comentou. Isso pode ser um indício de que efetivamente, o meio pode ser a mensagem, mas numa forma ampliada à que pensou McLuhan ${ }^{93}$. O meio não é o formato, mas a relação entre o autor, o meio e o leitor.

${ }^{93}$ MCLUHAN, Marshall. Os meios de comunicação como extensões do homem. São Paulo: Cultrix, 1974. 


\section{5 - UMA ALTERNATI VA TEÓRI CA PARA O J ORNALI SMO}

A internet mudou a comunicação humana de maneira significativa. Além de conectar os indivíduos, esse meio permite a criação de um sistema de informação e disseminação de notícias diferente de todos os meios de comunicação de massa surgidos anteriormente. A produção de conteúdos de forma colaborativa complementa e muitas vezes, discorda dos veículos da mídia tradicional.

“A novidade, portanto, está na existência de sites e sistemas de informação populares que só funcionam graças à colaboração dos usuários na publicação, troca e avaliação de conteúdos. Esses sites e sistemas, portanto, são auto-regulados, editados, moderados, comentados, rankeados e administrados pelos próprios usuários (ou com a colaboração deles). E já foram batizados de meios sociais ou meios cidadãos, pois é a sociedade que ativa tais meios e cria uma cultura generalizada de colaboração". ${ }^{94}$

Um site informativo com funcionamento nos moldes descritos acima é o portal Slashdot, especializado na cobertura da área de tecnologia ${ }^{95}$. O Slashdot representa o que muitos consideram o início da era do jornalismo open source, o que implica permitir que várias pessoas (não apenas jornalistas) escrevam e dêem sua opinião. A objetividade fica posta em segundo plano, com a busca pela qualidade da informação como o principal objetivo do portal.

\footnotetext{
${ }^{94}$ MALINI, F. Modelos de colaboração nos meios sociais da internet: uma análise a partir dos portais de jornalismo participativo, in:Web 2.0 - Participação e vigilância na era da comunicação distribuída. Henrique Antoun (org.), Rio de Janeiro, Mauad X, 2008.

${ }^{95}$ http://slashdot.org/
} 
O site tem 50 milhões de pageviews por mês e funciona apoiado em um sistema de moderação massiva. A primeira característica desse sistema é que a capa e o mural de discussão têm dinâmicas de atualização separadas.

São dois mundos interconectados: o planeta capa é o domínio dos editores. 0 planeta mural é gerido quase exclusivamente pela comunidade. Apenas os editores têm autorização para publicar na capa - para evitar que esse espaço seja controlado por grupos com causas específicas, como os opositores de Bill Gates e da Microsoft ou os interessados no debate sobre programação em código aberto e sobre o sistema operacional Linux.

A comunidade, por sua vez, fica responsável por garimpar as mensagens e apontar as mais interessantes. No planeta dos murais de discussão, a interferência dos editores é irrelevante: não passa de 3\%, segundo os números registrados pelo sistema. Ou seja, os usuários postam as mensagens e eles mesmos moderam esse material.

Nos murais, qualquer pessoa pode enviar a informação que desejar. Se o assunto for considerado relevante, atual ou apelativo, será escolhido e publicado por um dos editores do Slashdot que, diariamente, selecionam entre os artigos submetidos aqueles que preencherão o site, escolhendo os melhores ou mais atuais para a primeira página e dividindo os restantes pelas diversas seções. 
0 artigo publicado é, muitas vezes, apenas o início de uma longa lista de comentários que, como em qualquer fórum, acabam por ser não só reações ao artigo inicial, mas também, reações às reações. Como muitos dos utilizadores do Slashdot são especialistas, ler os comentários dos posts pode muitas vezes ser mais produtivo que ler o próprio artigo.

Embora muitos artigos sejam publicados sem grande ou mesmo nenhum conhecimento sobre a sua origem ou veracidade, isso é considerado um risco apenas para quem submete a informação, pois dados falsos ou infundados são normalmente detectados com rapidez pela comunidade. Conseqüentemente, a falsa informação é rara, o que possibilita um ambiente de segurança e assegura o sucesso do sistema.

Diante de todas as problemáticas levantadas na seção anterior, a questão fundamental a ser feita é: com a dificuldade das teorias lineares de Comunicação em entender a nova conformação do Jornalismo, existe alguma possibilidade teórica alternativa para este campo?

Durante a confecção do projeto de pesquisa e no período de preparação para o exame de admissão no mestrado, tomei contato com as teorias de sistemas emergentes e da complexidade. Um dos principais expoentes nessa linha de pesquisa sobre a Comunicação é o norte-americano Steve J ohnson. 
Johnson ${ }^{96}$, também jornalista, é um pensador do ciberespaço e que usa as teorias da complexidade e sistemas auto-emergentes para analisar processos não-lineares de comunicação e interação. Das mais diferentes áreas do conhecimento, termos como complexidade, sistema, padrões, interação e comportamento emergente são usados para analisar fenômenos que fogem das estruturas hierárquicas convencionais.

“Temas como a inteligência emergente (Johnson, 2001), coletivos inteligentes (Rheingold, 2002), cérebro global (Heylighen et al., 1999), sociedade da mente (Minsk, 1997), inteligência conectiva (Kerckhove, 1997), redes inteligentes (Barabási, 2002), inteligência coletiva (Levy, 2002) são cada vez mais recorrentes. Todos eles apontam para uma mesma situação: estamos em rede, interconectados com um número cada vez maior de pontos, numa frequência que só faz crescer. Além disso, a disseminação de dispositivos móveis(...) (...) torna claro o desejo de compreender melhor a atividade desses coletivos, a forma como comportamentos e idéias se propagam, o modo como notícias afluem de um ponto a outro do planeta" (grifo nosso) ${ }^{97}$

Essa tentativa de análise da realidade e de construção teórica vai ao encontro dos objetivos deste trabalho. Nossa intenção é entender e conceituar fenômenos recentes o primeiro blog data de 1997 - e estabelecer novos parâmetros para a Comunicação e para o Jornalismo veiculados por meios digitais e produzidos com uso das mais diferentes plataformas tecnológicas.

\footnotetext{
96 JONHSON, Steve. Emergência - a Dinâmica de Rede em Formigas, Cérebros, Cidades e Softwares, Rio de Janeiro, Zahar, 2003.

${ }^{97}$ COSTA, R. Por um novo conceito de comunidade: redes sociais, comunidades pessoais e inteligência coletiva, in: Web 2.0 - Participação e vigilância na era da comunicação distribuída. Henrique Antoun (org.), Rio de Janeiro, Mauad X, 2008.
} 
Uma das características da teoria a embasar o pensamento auto-emergente é a percepção dos sinais emitidos pelo sistema como um todo, em suma, a deteç̧ão de padrões. Aqui estaria a conexão buscada com o Jornalismo, pois no procedimento de editar e escolher quais notícias devem ser veiculadas, o jornalista segue padrões.

De forma análoga ao que preconiza essa corrente teórica, muitas vezes o editor não se dá conta desses padrões norteadores do seu trabalho. A pressão do fechamento e a necessidade de veicular a notícia antes do seu concorrente impede uma análise mais apurada. No entanto, ao olharmos as capas dos jornais diariamente notamos muitas semelhanças entre as escolhas feitas pelos diferentes jornais.

Vejamos como J ohnson aborda os sistemas emergentes: "Somente pela observação de todo o sistema em ação é que o comportamento global se manifesta. (...) Sistemas emergentes podem ficar fora de controle quando suas partes componentes se tornam excessivamente complicadas". Ainda: "Essa aptidão para detectar padrões permite a circulação de meta-informação: sinais acerca de sinais". ${ }^{.98}$

Chegamos a outro ponto importante da criação, armazenamento e veiculação das notícias nos dias de hoje: boa parte dessas informações está indexada através das categorias e tags das notícias e posts midiatizados pela Internet. Essas informações são

\footnotetext{
${ }^{98}$ Idem. P 57.
} 
chamadas de meta-dados e permitem aos editores compreender o comportamento da audiência e direcionar o fluxo da edição.

0 terceiro aspecto da informação digital relaciona-se com o comportamento emergente ao procurar, ler e disseminar as notícias. 0 intuito ao classificar a informação é tornar seu acesso mais fácil para quem as lê e para quem as produz. Prossegue Johnson em sua explanação sobre sistemas emergentes:

“O corpo aprende sem consciência, e também as cidades, porque aprender não quer dizer apenas estar consciente da informação; é também armazenar informação e saber onde encontrá-la. É ser capaz de reconhecer e responder a mudanças de padrões (...), é alterar o comportamento de um sistema em resposta a padrões, de modo a torná-lo mais capaz de atingir o objetivo a que se propõe. (...) Esse padrão que se mantém no tempo é um dos pequenos milagres da emergência. (...)".

Isso nos leva à seguinte questão: a web também está aprendendo? Se é fato que as cidades podem gerar inteligência emergente - um macro-comportamento provocado por milhões de micro-motivos -, que forma de nível mais alto está sendo gerada entro os roteadores e os cabos de fibra ótica da Internet? Será que ela (a Internet) está se tornando mais organizada à medida que cresce?"199

${ }^{99}$ Idem. Pgs 60-87. 
O trecho a seguir nos fornece mais uma prova de como a estrutura da Internet e, portanto, a veiculação de notícias nesse meio não segue uma lógica linear:

"A distribuição dos sites da Internet e seus públicos parece seguir o que é chamado de lei de potência: os dez mil sites mais populares são dez vezes maiores do que os próximos cem mais populares, que, por sua vez, são dez vezes mais populares que os próximos mil (...) (...) Esses padrões podem ser auto-organizáveis, mas não são, de nenhuma maneira, adaptáveis. Compare-o com os padrões dinâmicos, vivos dos bairros de uma cidade ou do cérebro humano". ${ }^{100}$

À época do lançamento do livro, mecanismos de feedback na web eram pouco desenvolvidos. Isso aproximava muito a disseminação de informações na Internet da atividade jornalística em meios impressos e na televisão - controlar o caos de informações e fatos e utilizar a resposta do público para dimensionar e estabelecer uma forma organizada de trabalhar estruturas de edição.

Segundo Johnson, a web pode nunca se tornar autoconsciente de maneira a se assemelhar à consciência humana, "o que não quer dizer que ela não seja capaz de aprender. Nossas redes ficarão muito mais inteligentes nos próximos anos". ${ }^{101}$

A previsão mostrou-se acertada, conforme expusemos acima: hoje há mecanismos de aferição de audiência de notícias em tempo real, mostrando inclusive a origem do

\footnotetext{
${ }^{100}$ Idem.

101 Idem. Pág. 94.
} 
tráfego para determinada notícia. No mesmo livro, o autor faz considerações sobre um acontecimento comum na cobertura jornalística, popularmente conhecido como "efeitocascata":

"Atualmente, os meios de informação alimentam frenesis, e a cobertura de uma história naturalmente gera mais cobertura" (...) (...) "Em geral, pode-se detectar um desses círculos de feedback quando seu desenlace está próximo, pois quase invariavelmente ele dispara uma onde de auto-aversão que lava tudo o que foi comentado. Mas os círculos de feedback da década de 1990, não eram inevitáveis, apareceram graças a mudanças específicas no sistema subjacente dos meios de comunicação de massa".

Essas mudanças trouxeram os primeiros sinais de emergência - e anteciparam os genuínos sistemas bottom-up que, desde então, floresceram na web. Esse fato não é surpreendente: todos os sistemas descentralizados baseiam-se extensamente em feedback, tanto para o crescimento quanto para a auto-regulação. ${ }^{102}$ Cabe uma pequena explanação sobre a definição de sistemas emergentes:

Nos sistemas emergentes, também chamados bottom-up (de baixo para cima), agentes que residem em uma escala começam a produzir um comportamento cujo padrão reside em uma escala acima deles: formigas criam colônias, cidadãos criam comunidades, um software de reconhecimento de padrões aprende como recomendar novos livros.

${ }^{102}$ Idem. Pág. 98-99. 
O movimento das regras de nível baixo para a sofisticação do nível mais alto é o que 0 autor chama de emergência. O sistema só é emergente quando todas as interações locais resultam em algum tipo de macrocomportamento observável. Deve ainda ter os seguintes componentes: interação entre vizinhos, reconhecimento de padrões, feedback e controle indireto. ${ }^{103}$

Aumenta a importância de cada elemento do sistema midiático, portanto. J ohnson não se refere apenas ao mundo online. A televisão, hoje, atinge $99 \%$ dos lares brasileiros e a disseminação de informação é muito maior e mais veloz. E quanto mais informação disponível, mais o sistema realimenta a si mesmo.

No entanto, o sistema encontra um modo de defender-se dessa retroalimentação, muitas vezes causada pela pouca cautela na veiculação de notícias: "Uma resposta plausível se resume a um termo familiar a mídia de hoje: fadiga. Explica o autor:

“Cada neurônio de cérebro sobre de uma espécie de impotência regulada; após um período de atividade, a célula precisa de alguns milésimos de inação, o 'período refratário absoluto', durante os quais é imune a estímulos exteriores. (...) é uma maneira de diminuir a reverberação do circuito, mantendo controle sobre a auto-alimentação frenética do cérebro. É esse curto-circuito que está faltando na vasta interconexão da mídia moderna".

\footnotetext{
${ }^{103}$ Cf. http://www.comciencia.br/resenhas/2005/10/resenha1.htm
} 
Nesse momento, Johnson se aproxima das teorias da Escola de Frankfurt e critica o uso da audiência e dos anunciantes como o único feedback a ser seguido. A decisão individual do repórter ou editor sucumbe às pressões mercadológicas e outra vez encontramos as leis fundamentais da emergência: o comportamento dos agentes individuais é menos importante que o sistema como um todo.

Pela primeira vez o sistema começou a reverberar por si próprio. Ainda assim, a estrutura pesada dos meios de comunicação de massa pode conservar esses círculos relativamente mudos por um futuro previsível, ao menos no que se refere à televisão. Afinal de contas, o feedback em geral não é uma coisa de televisão. "Precisamos da web para ouvir seu gemido". ${ }^{104}$

Por fim, Johnson também discute a possibilidade de um mundo dominado pelo usuário leitor das notícias na web. 0 autor lança uma pergunta e aventa a idéia da personalização total das notícias, ou seja, um mecanismo de mediação direta entre o leitor e a plataforma de veiculação das notícias: "Há algum perigo em ir para um mundo onde toda a mídia responde diretamente ao feedback do usuário?".

O questionamento é uma resposta a Nicholas Negroponte, professor do MIT e também teórico do mundo digital. Para Negroponte, no futuro, os jornais seriam editados perfeitamente de acordo com os desejos do usuário. Esse jornal seria tão personalizado

\footnotetext{
${ }^{104}$ Idem. Pág. 107.
} 
que o leitor perde uma das características constitutivas do Jornalismo e da teoria da notícia: o valor e a surpresa que espera da leitura de um jornal.

Caso isso efetivamente ocorra e o Daily Me torne-se realidade, o leitor jamais iria encontrar assuntos novos, pontos de vista discordantes das suas opiniões costumeiras. o Daily Me simplesmente retorna para você aquilo que o programa foi instruído a buscar.

Novamente, a suposição de Johnson se mostra acertada: apesar das widgets de personalização de notícias e dos leitores de RSS (que enviam a você o conteúdo desejado), os portais não morreram. Mas eles irão mudar.

"Os comportamentos emergentes, assim como os jogos, vivem dentro dos limites definidos pelas regras, mas também usam esse espaço para criar algo maior do que a soma das partes", diz Johnson. A situação prevista pelo autor pode ser verificada já em 2009:

"A maioria das tentativas de especular sobre o estado da web daqui a cinco anos focaliza o sonho minuciosamente avaliado da convergência: a divina trindade de vídeo, áudio e texto afinal introduzida em sua sala por um único mecanismo de transmissão (...). Os críticos gostam de nos dizer que, uma vez alcançado esse limite, o universo tradicional da mídia não mais obedecerá à sua anterior lei da gravidade e uma nova ordem emergirá. Como será essa nova ordem é matéria para intensos debates. A sobrecarga de 
informação apresentada por bilhões ou mais de páginas HTML nos forçou a desenvolver ferramentas para administrar essa saturação, instrumentos que eliminam a necessidade de editores ou arquivistas centralizados (...)" 105

${ }^{105}$ Idem. Pág. 135-162. 


\section{6 - CONSI DERAÇÕES FI NAIS}

Nos últimos 10 anos, o surgimento de algumas ferramentas tecnológicas transformou a maneira de fazer Jornalismo. As rotinas de produção e veiculação de notícias foram alteradas com a adoção de plataformas tecnológicas de publicação baseadas na Internet.

Duas dessas ferramentas são os blogs e os wikis. Inicialmente concebidas como ferramentas de publicação online, acabaram sendo utilizadas também para produzir conteúdo informativo e jornalístico. Mas o uso dos blogs e wikis afetam alguns pressupostos do J ornalismo tradicional.

Com a simplificação dos recursos, a manutenção desses sites ficou mais fácil e isso contribuiu para a popularização das duas plataformas. Segundo pesquisa realizada pela Verbeat.org entre blogueiros brasileiros em 2006, 61,4\% desses produtores de conteúdo percebe os blogs como uma forma de Jornalismo.

Essa percepção é escorada em algumas características similares entre os blogs e o J ornalismo: atualização constante e textos publicados em ordem cronológica inversa, conforme apontam as pesquisadoras de redes sociais Amaral, Montardo e Recuero no artigo Blogs: mapeando um objeto ${ }^{106}$ (2003).

\footnotetext{
${ }^{106}$ Cf. http://www.midiasdigitais.org/2008/01/blogs-mapeando-um-objeto/
} 
A primeira diferença causada pelos blogs na rotina produtiva dos jornalistas consiste na mudança do conceito de fechamento. Nos meios impressos, esse conceito estava ligado à produção jornalística veiculada num determinado período e afetada por limitações de prazo.

Outra mudança está no aspecto funcional do Jornalismo. O caráter dialógico da comunicação oral é recuperado pelos blogs. As três principais vertentes da teoria da Comunicação encaram os mídia de modo unidirecional. Conforme vimos no capítulo 2, as teorias funcionalistas, da Escola de Frankfurt e os Estudos Culturais adotam o esquema emissor-canal- receptor.

A velocidade e interatividade das publicações online, aliadas às caixas de comentários dos blogs e as possibilidades de produção colaborativa dos wikis criam uma comunicação mais horizontal. Ficam diminuídas as barreiras entre os jornalistas e seus leitores.

Um terceiro ponto está na discussão sobre as noções de imparcialidade e objetividade, constitutivas do J ornalismo praticado entre os séculos XVIII e XX. Blogs têm um caráter muito mais opinativo. Por isso, teóricos como Jay Rosen, da New York University, discutem se os blogs podem ser considerados veículos jornalísticos. 
Por fim, há a questão da veracidade e credibilidade das informações divulgadas em blogs e wikis. Ainda não foram encontrados mecanismos eficientes para a checagem de informações nesses veículos. No entanto, essas plataformas suscitam um paradoxo interessante: quanto mais usuários, maior o risco de haver informação errada. Porém, a correção também acontece mais rapidamente.

Segundo pesquisa divulgada pelo Ibope em $2008,43 \%$ das pessoas já utiliza a Internet como fonte primária de informação. Isso coloca os meios digitais como a principal fonte de informação. Os blogs são parte fundamental na construção dessa rede de divulgação de informações online.

Outro fator a ser considerado é a queda acentuada nas vendas dos jornais impressos. No período 2000-2004, a queda verificada no Brasil chegou à 20\%. Nos EUA, apenas no último ano, a queda é de $7 \%$. Os grandes conglomerados de mídia já pensam em maneiras de alterar seus modelos de negócio - há a hipótese dos conglomerados de mídia voltarem a cobrar pelo conteúdo disponibilizado na Internet.

Mudanças no modelo de negócios das empresas de mídia, mudanças também no perfil profissional do jornalista com a chegada de novas tecnologias. Com um processo de fechamento permanente e alteração da percepção dos conceitos de edição, publicação e autoria das notícias, haverá mais interação entre as funções de repórter e editor. 
Essas constatações demonstram a necessidade de profissionais e acadêmicos pensarem em novas metodologias e mesmo em novas teorias para compreender a conformação do J ornalismo no século XXI. Quais devem ser os parâmetros éticos, estéticos e técnicos da profissão nos dias de hoje?

Nesse sentido, autores como Dominique Wolton e Luiz Martino levantam questionamentos pertinentes sobre o status epistemológico do campo da Comunicação. Carlos Chaparro, Bernardo Kucinski, Pollyana Ferrari e Felipe Pena abordam necessidades da Teoria do J ornalismo em sua vertente digital.

Ronaldo Henn e Steve Johnson trazem formulações teóricas criadas por outros campos do conhecimento, principalmente da Física e da Biologia, na tentativa de compreender as mudanças ocorridas após o desenvolvimento das plataformas tecnológicas e sua posterior aplicação ao J ornalismo online.

A discussão sobre o estatuto epistemológico da Comunicação é uma questão não resolvida desde os primeiros estudos sobre o tema, ainda nas primeiras décadas do século XX. Com a utilização de novas plataformas de publicação e sua influência no modus operandi das redações, é necessário pensar uma nova maneira de entender as relações entre o J ornalismo e a sociedade. 
Num cenário onde o jornalista não mais detém o monopólio das fontes de informação e todos podem produzir e veicular notícias, parece clara a falência do modelo unidirecional da Comunicação. Nesse sentido, teorias da complexidade e da auto-organização seriam mais adequadas para estudar o fenômeno comunicacional.

Seja na formulação dos sistemas auto-organizáveis, seja na teoria dos sistemas complexos, uma característica é fundamental para o funcionamento do sistema, a saber, a retro-alimentação. Os comentários em blogs e as correções em matérias produzidas em conjunto restauraram a dimensão dialógica e complexa da Comunicação para os processos de informação midiática.

Para Wolton, a redução da Comunicação a uma mera técnica, a um conhecimento de segunda ordem, é o primeiro fator a explicar a falta de estudos mais aprofundados na área. A dificuldade de entender os processos de recepção da informação produzida pelos mídia também contribui para a existência dessa lacuna teórica.

Segundo o teórico francês, a resistência a estudar a Comunicação e as transformações surgidas com o advento das plataformas tecnológicas baseadas na Internet vem dos meios intelectuais. Os intelectuais se sentiram ameaçados com o surgimento das mídias de massa. 
Esses veículos aumentaram exponencialmente a quantidade de informação disponível e apagaram as fronteiras entre a cultura de elite, cultura de massa e cultura particular. Ignorar esse fato foi a maneira encontrada pelos intelectuais para se defender de todas essas mudanças, segundo Wolton.

Como reflexo dessa recusa em estudar a Comunicação mais profundamente, aconteceu um impasse epistemológico. Segundo Luiz Martino, muitos chegam a negar a existência de uma teoria própria à Comunicação, pois a maioria das formulações teóricas era proveniente de outros campos do conhecimento.

Desse modo, chegamos a uma constatação contraditória: há a necessidade de propor uma teoria sobre a Comunicação e ao mesmo tempo negar a esse campo do conhecimento sua autonomia epistemológica. A interdisciplinaridade da Comunicação e a falta de delimitação de seu objeto causam uma dispersão teórica difícil de ser resolvida.

Martino ${ }^{107}$ levanta uma hipótese sobre essa dificuldade epistemológica: não há distinção entre as teorias sobre Comunicação e as teorias da Comunicação. As primeiras, vindas de outros campos explicariam esse fenômeno em perspectiva; já as segundas explicariam a Comunicação enquanto saber autônomo e com demandas metodológicas específicas.

${ }^{107}$ MARTINO, L. (org.), Teorias da Comunicação: muitas ou poucas? Ateliê Editorial, 2007. 
A quantidade de temas estudados sob o "guarda-chuva" epistemológico da Comunicação é prova da falta de uma delimitação mais adequada do objeto a ser estudado. Charles Berger se pergunta sobre a possibilidade de os esforços de pesquisa serem orientados por um número menor de questões epistemológicas. Isso ajudaria na fundamentação do campo da Comunicação.

De maneira análoga, o mesmo problema é verificado quando nos debruçamos sobre as chamadas teorias do Jornalismo. Conforme atesta J orge Souza, não há consenso sobre a possibilidade de construção de uma teoria do Jornalismo centrada na produção, veiculação e consumo das notícias.

A constatação causa preocupação quando pensamos na quantidade cada vez maior de produção e consumo de notícias nos dias atuais. Segundo pesquisa realizada pela Universidade da Califórnia, a quantidade de informação disponível dobra a cada 18 meses. Só a informação produzida no período entre 2000 e 2009 já é superior a toda informação produzida anteriormente.

Conforme explica Traquina, o Jornalismo é uma atividade intelectual e não deve ser reduzida ao domínio de uma série de técnicas usadas para disseminar informação. Uma teoria do Jornalismo, para Souza, deve explicar as notícias e seus efeitos na sociedade confirmando o efeito de retro-alimentação no relacionamento dos veículos de mídia com a sociedade. 
Essa discussão engloba as plataformas utilizadas para a produção das matérias jornalísticas. Os meios digitais potencializam duas características da relação entre o Jornalismo e a sociedade: a simplificação, a velocidade e a interatividade entre os emissores e receptores da produção midiática.

Um dos efeitos da migração do J ornalismo dos meios impressos para os meios digitais é a perda da profundidade das reportagens e do conteúdo veiculado. Com a crise econômica causada pela queda das bolsas no ano 2000, o conjunto de fontes de informação foi reduzido. Assim, leitores de diferentes portais passaram a receber o mesmo conteúdo, salvo pequenos acréscimos editoriais.

Portanto, cumpre estudar os meios digitais e suas características inerentes, de modo a explorar todas as possibilidades trazidas por essas mídias - imagens, vídeos, conteúdos de voz e interatividade entre os produtores e leitores desse conteúdo. 0 principal desafio dos portais é tornar a recepção das notícias cada vez mais intuitiva.

Nesse sentido, o papel dos editores ficará mais preponderante. No passado, havia dificuldade em obter informação. Hoje, ela existe em abundancia - prova disso são as 10 bilhões de páginas na Internet. A questão a ser colocada é o gerenciamento eficiente de tanto conteúdo. 
Como antes o leitor não tinha acesso às fontes de informação, era importante destacar as notícias mais importantes. Isso explica a existência da capa nos jornais impressos. Hoje, a procura por informações é muito mais específica, dinâmica e caótica.

Esse estado de coisas é explicado de modo mais satisfatório por uma teoria do Jornalismo baseada num modelo não-linear, cujo pressuposto é um sistema onde a ordem não é imposta. 0 sistema tem um comportamento macroscópico emergente devido às ações dos milhares de micro-componentes.

A diferença estrutural num sistema como esse é a necessidade da participação dos usuários para que ele funcione. Um site noticioso baseado na colaboração dos leitores para publicação, recomendação e avaliação de notícias só pode ser entendido pela teoria de sistemas emergentes.

Talvez esteja nessa concepção teórica a alternativa buscada para compreender o aparecimento de mídias como blogs e wikis e entender também as alterações sofridas pelo J ornalismo com a utilização dessas ferramentas.

Muitas vezes, o jornalista não se dá conta dos padrões e escolhas feitas no seu trabalho de apuração e edição dos acontecimentos. Esse padrão só emerge quando visualizamos o jornal impresso. É interessante notar as semelhanças na edição de dois jornais geograficamente distantes. 
Nesse caso, a teoria de sistemas emergentes poderia explicar por que tais coincidências acontecem. Segundo Steve Johnson, "Somente pela observação de todo o sistema em ação é que o comportamento global se manifesta. Sistemas emergentes podem ficar fora de controle quando seus componentes se tornam excessivamente complicados".

Outro aspecto importante dos sistemas emergentes é a aptidão para detectar padrões, permitindo a circulação de meta-informação: sinais acerca de sinais. Boa parte das informações veiculadas na Internet está indexada por meio de categorias e tags. Isso ajuda a compreender o comportamento da audiência e orienta o fluxo editorial.

Uma tag (etiqueta em inglês) é uma palavra-chave ou termo associado com uma informação, permitindo descrever a informação por meio do uso dessas palavras-chave. Tags são, usualmente, escolhidas informalmente pelo autor ou criador do item de conteúdo - isto é, não são parte de um esquema formal de classificação. É um recurso encontrado em muitos sites de conteúdo colaborativo e por essa razão, associado com a Web 2.0. ${ }^{108}$

Ao categorizar a informação, auxiliamos tanto a quem procura quanto a quem produz informação. Isso ajuda o sistema midiático a atingir mais facilmente o seu objetivo: disseminar informação. Assim surgem as recomendações de notícias, baseadas nas notícias lidas anteriormente por um usuário do site.

\footnotetext{
${ }^{108}$ http://pt.wikipedia.org/wiki/Tag_(metadata)
} 
Sistemas descentralizados de informação só funcionam adequadamente se utilizam estruturas de realimentação como as descritas acima. Isso justifica a criação de estruturas editoriais baseadas em notícias relacionadas ou indicar quais as notícias mais lidas do dia.

Mas há riscos caso haja uma total personalização das estruturas de veiculação de notícias. Ainda segundo Johnson, caso os portais informativos fossem editados totalmente de acordo com os desejos do usuário, haveria a perda de uma característica fundamental do J ornalismo: a chance de se deparar com uma notícia inesperada.

Caso o leitor abdique de ler os portais e só receba notícias sob demanda, ele nunca irá encontrar notícias de assuntos que não os preferidos por ele ou mesmo de encontrar um artigo opinativo com uma visão discordante. É preciso que haja um espaço para que o sistema emergente consiga criar algo maior do que a soma das partes.

Assim, esperamos ter demonstrado com este trabalho a pertinência de estudarmos o Jornalismo na atualidade à luz de teorias como a de sistemas emergentes e da complexidade. Tais abordagens teóricas podem auxiliar os pesquisadores da área a entender como as ferramentas tecnológicas estão mudando a maneira de produzir e veicular as notícias. 


\section{BI BLI OGRAFI A}

ADORNO e HORKHEIMER. A Indústria Cultural. "O I/uminismo como mistificação das massas", in: LIMA, L. Teoria da Cultura de Massa. Paz e Terra, RJ, 1978.

AMARAL, A, MONTARDO, S, RECUERO, R. Blogs: mapeando um objeto. Disponível em: http://pontomidia.com.br/raquel/AmaralMontardoRecuero.pdf, Rio de Janeiro, 2003.

ANTOUN, H. (org.) Web 2.0 - Participação e vigilância na era da comunicação distribuída, Rio de Janeiro, Mauad X, 2008.

BATESON, G. Steps to an Ecology of Mind. Chicago e Londres, The University of Chicago Press, 2000. Edição original 1972.

BORDENAVE, J. Além dos Meios e Mensagens - Introdução à comunicação como processo, tecnologia, sistema e ciência, Vozes, Petrópolis, 1983.

BORDIEU, P. Sobre a Televisão. Jorge Zahar, Rio de Janeiro, 1997.

CASAgRande, T e Gej finBei N, L. Pesquisa Blogosfera Brasil. Porto Alegre, 2006. Disponível em: http://www.verbeat.org/pesquisablogosferabrasil CASTELLS, M. A Sociedade em Rede. 3a edição, Paz e Terra, São Paulo, 2000. CHAPARRO, M. Pragmática do Jornalismo - Buscas Práticas para uma Teoria da Ação Jornalística. Summus, São Paulo, 1993.

COHN, G. (org). Comunicação e indústria cultural. São Paulo: Cia. Editora Nacional, 1978.

CÔNSOLO FILHO, S. A comunicação contemporânea e o J ornalismo na web: análise dos portais UOL e Estadão.com em um mundo mercadológico. Dissertação de Mestrado, Faculdade Cásper Líbero, São Paulo, junho de 2009. 
DENICOLI, S. Vendas de jornais impressos em queda acentuada, Ponto de análise, São Paulo, 13/03/2006. Disponível em http://pontodeanalises.blogspot.com/2006/03/vendade-jornais-impressos-em-queda.html FERRARI, P. Jornalismo Digital. Editora Contexto, São Paulo, 2003. von FOERSTER, H. Conhecimento e Consciência, (Org. Siegfried J. Schmidt, Frankfurt am Main, Suhrkamp. 1994

GILLMOR, D. We the Media: Grassroots Journalism By the People, For the People. Oreilly \& Assoc, 2004.

GOMES, P. Tópicos de Teoria da Comunicação, São Leopoldo, editora Unisinos, 2001. GREENSLADE, R. US Newspaper sales fall further. The Guardian, Londres, 28/04/2009. Disponível em: http://www.guardian.co.uk/media/greenslade/2009/apr/28/us-presspublishing-abcs HABERMAS, J. Mudança estrutural da esfera pública: investigações quanto a uma categoria da sociedade burguesa. Rio de Janeiro, Tempo Brasileiro, 1984.

HALL, S. A Identidade Cultural na Pós-Modernidade. DP\&A editora, Rio de Janeiro, 2000. HENN, R. Os Fluxos da Notícia, uma semiose sistêmica, Unisinos, São Leopoldo, 2002. HORGAN, J. O Fim da Ciência - Uma discussão sobre os limites do conhecimento científico, Cia das Letras, São Paulo, 1998.

JOHNSON, S. Cultura da Interface, Como o Computador Transforma Nossa Maneira de Criar e Comunicar. J orge Zahar, Rio de Janeiro, 2001.

IDEM. Emergência - a dinâmica de rede em formigas, cérebros, cidades e softwares. J orge Zahar, Rio de J aneiro, 2003. 
KEEN, A. O culto do amador - como a internet está matando a nossa cultura. Nova York, 2007.

KOVACH, B e ROSENTIEL, T. Os Elementos do Jornalismo, editora Geração, São Paulo, 2003.

KUNCZIK, M. Conceitos de J ornalismo. Edusp/ Com Arte, São Paulo, 1997.

KUCINSKI, B. Jornalismo na era virtual - ensaios sobre o colapso da razão ética. Editora Unesp, São Paulo, 2005.

LAGO, C e BENETTI, M. Metodologia da Pesquisa em Jornalismo, Vozes, Petrópolis, 2007.

MARLOW, C. Audience, structure and authority in the weblog community. In: Presented at the International Communication Association Conference, May, 2004, New Orleans, LA. 2004 MAROCCO, B e BERGER, C. A Era Glacial do Jornalismo, Sulina, volume I, Porto Alegre, 2006.

MARTIN-BARBERO, J. Dos Meios às Mediações - Comunicação, Cultura e Hegemonia, editora UFRJ, Rio de Janeiro, 1997.

MARTINO, L. (org.), Teorias da Comunicação: muitas ou poucas? Ateliê Editorial, 2007. MATTELART, Armand e Michele. História das Teorias da Comunicação. Loyola, São Paulo, 1999.

MATURANA, H. e VARELA, F. De máquinas e seres vivos. Autopoiese, a Organização do Vivo. Porto Alegre: Artes Médicas, 1997. 
MCLUHAN, Marshall. Os meios de comunicação como extensões do homem. São Paulo: Cultrix, 1974

MEDITSCH, E., O jornalismo é uma forma de conhecimento? In Media e J ornalismo, no 1, № 1, Ano 1, Florianópolis, 2002

MELO, J osé Marques de. "Ensino de Graduação em Comunicação Social: paradigmas curriculares". Revista Brasileira de Ciências da Comunicação, Identidades Comunicacionais, ano XXI, número 01, janeiro/junho de 1998. Intercom, São Paulo. IDEM. Comunicação Social, teoria e pesquisa. Vozes, Petrópolis, 1973.

NEGROPONTE, N. A Vida Digital, Cia das Letras, São Paulo, 1995.

NORMAN, D. O Design do Dia-a-dia. Rocco, 2006.

ORTIZ, R. Mundialização e Cultura. Brasiliense, São Paulo, 1994.

PENA, F. Teoria do Jornalismo, Editora Contexto, São Paulo, 2005.

PEUCER, T. Os Relatos jornalísticos (tradução de Paulo da Rocha Dias), in Estudos de J ornalismo e Mídia, o 02, volume 1, Insular, Santa Catarina, 2004.

PÓVOA, M. Anatomia da Internet - investigações estratégicas sobre o universo digital. Casa da palavra, Rio de Janeiro, 2000

PRIGOGI NE I. \& Stengers, I. La nouvelle alliance. Gallimard, Paris, 1986.

RAMADAN, N. Tese de Livre-docência, "O Jornalismo online visto pelos pesquisadores em São Paulo: a fragilidade das pesquisas que fazem escola (equivocada) nos bancos da graduação", ECA-USP, 2008.

SANTOS, M. Técnica Espaço/Tempo - Globalização e Meio Informacional. Hucitec, São Paulo, 1994. 
IDEM, Por uma outra Globalização, do Pensamento Único à Consciência Universal_ Record, Rio de Janeiro, 2000.

SANTOS, R. Introdução à teoria da Comunicação, São Bernardo do Campo, Editora Bartira, 1992

SCHMIDT, J. Blogging practices: An analytical framework. In: Journal of ComputerMediated Communication, 12(4), article 13. 2007. Disponível em:

http://jcmc.indiana.edu/vol12/issue4/schmidt.html

SODRÉ, M. Antropológica do Espelho - uma teoria da comunicação linear e em rede, Vozes, Petrópolis, 2002.

SOUZA, J. "Por que as notícias são como são? Construindo uma teoria da notícia" in Pauta Geral, Revista de J ornalismo, editora Calandra, Salvador, ano 10, № 05, 2003. TRAQUINA, N. O que é Jornalismo. Quimera, Lisboa, 2002.

IDEM. Teorias do Jornalismo - porque as notícias são como são - volume I, editora Insular, Florianópolis, 2004.

IDEM. Teorias do Jornalismo - a tribo jornalística, uma comunidade transnacional, volume II, Insular, Florianópolis, 2005.

WIENER, N. Cibernética e Sociedade - O Uso de Humanos de seres humanos. Cultrix, São Paulo, 1954.

WOLF, M. Teorias da Comunicação, editorial Presença, Lisboa, 1995.

WOLTON, D. Internet, e Depois? Uma teoria crítica das novas mídias. Sulina, Porto Alegre, 2003. 